\title{
The Tumor Necrosis Factor Receptor and Human Neutrophil Function \\ Deactivation and Cross-deactivation of Tumor Necrosis Factor-induced \\ Neutrophil Responses by Receptor Down-regulation
}

Boris Schleiffenbaum and Jorg Fohr

Division of Hematology, Department of Internal Medicine, University Hospital, CH-8091 Zürich, Switzerland

\begin{abstract}
Despite numerous reports, the role of tumor necrosis factor (TNF) in polymorphonuclear leukocyte (PMN) function remains controversial. We found TNF to be a potent, pertussis toxin-independent stimulator of PMN adhesion (ED 2.6 pM). TNF-stimulated PMN under adherent conditions released up to $65 \%$ of their transcobalamine content $\left(E D_{50} 3.9\right.$ pM) and increased their burst activity 10-fold (ED 3.2 pM) as measured by the hexose monophosphate shunt, whereas PMN held in suspension hardly degranulated at all and only little burst activity was demonstrable. However, preincubation of PMN with TNF in suspension led to a decrease in cellular adhesiveness, degranulation, and burst activity in response to a secondary stimulus of TNF under adherent conditions, although cells remained fully responsive toward phorbol myristate acetate. A concomitant dose-dependent decline of TNF receptor numbers that correlated well with the inhibition of PMN function ( $r=0.91$ ) suggests receptor down-regulation as the mechanism of functional PMN deactivation. Remarkably, preincubation with other PMN stimuli such as $\mathbf{N}$-formyl-methionyl-leucyl-phenylalanine, platelet-activating factor, leukotriene $\mathrm{B}_{4}$, complement component fragment 5a (C5a)/C5a (desarginated), and endotoxin also led to a reduction of TNF-specific PMN responses (cross-deactivation) from 35\% $\left(\mathbf{L T B}_{4}\right)$ to 90\% (endotoxin), corresponding with the down-regulation of TNF receptors. Deactivation and receptor down-regulation are independent of pertussis toxin-sensitive $G$ proteins and protein kinase $\mathbf{C}$ but seemed to depend on changes in calcium metabolism. Granulocyte hyporesponsiveness towards TNF in sepsis (with elevated blood levels of endotoxin and TNF) might be a mechanism of self-protection or, to the contrary, might impair a possibly central mode of host defense. (J. Clin. Invest. 1990. 86:184-195.) Key words: deactivation - function polymorphonuclear leukocyte • receptor • tumor necrosis factor
\end{abstract}

\section{Introduction}

Tumor necrosis factor (TNF) ${ }^{1}$ or cachectin, a glycoprotein of $17,000 \mathrm{~mol} \mathrm{wt}$, has, apart from its cytotoxicity towards certain

Address reprint requests to Dr. J. Fehr, Department of Medicine, A-Hof-149, University Hospital, CH-8091 Zurich, Switzerland.

Received for publication 23 June 1989 and in revised form 29 December 1989.

1. Abbreviations used in this paper: $\mathrm{C5}$ a and C5a desarg, complement component fragment $5 \mathrm{a}$ and complement component fragment $5 \mathrm{a}$,

J. Clin. Invest.

(c) The American Society for Clinical Investigation, Inc.

0021-9738/90/07/0184/12 \$2.00

Volume 86, July 1990, 184-195 tumor cells (1) and the suppression of lipoprotein lipase activity in adipocytes $(2,3)$, pleiotropic effects on a large number of different cell types including fibroblasts (4), osteoclasts (5), and endothelial cells, in which TNF induces procoagulant activity (6), adhesion (7), and transmigration of granulocytes $(8,9)$. Its role in the stimulation of polymorphonuclear leukocytes (PMN), however, has been controversial. Some authors found TNF to be only a weak direct stimulus of the neutrophil respiratory burst and degranulation and to act essentially as a primer of PMN phagocytosis (10), antibody-dependent cellular cytotoxicity (ADCC [11]), or PMN responses to secondary stimuli such as $\mathrm{N}$-formyl-methionyl-leucyl-phenylalanine (FMLP [12]). In contrast, others presented data that showed TNF to be a potent stimulus of the respiratory burst of neutrophils $(13,14)$. Starting out from the concept that PMN adhesion strongly promotes neutrophil functional responses (15, 16), it was suggested that differences in incubation conditions could explain these conflicting results: whereas PMN in suspension showed hardly any stimulation of degranulation or respiratory burst, adherent PMN did (with or without cytochalasin B [17]).

Although it has proven to be difficult to isolate and characterize the TNF receptor biochemically (18-20), there is good evidence that TNF effects are mediated via a ligand-receptor system. High-affinity binding sites on tumor cells are necessary, although not sufficient for tumor cell sensitivity towards TNF-induced cytotoxicity $(4,18,20)$. On PMN, the expression of high-affinity binding sites for TNF could be demonstrated as well and was correlated to PMN stimulation (21). Possibly owing to the lack of unequivocal TNF-induced functional data, there has been little interest in the further characterization of the TNF receptor on neutrophils, and the amount of information on the TNF receptor on neutrophils has remained relatively scarce compared to, for example, FMLP and its receptor. Specific PMN deactivation towards FMLP, i.e., cellular desensitization by preexposure to the same stimulus, has been thoroughly investigated and has been attributed to a reduction in receptor availability (22-24). Whether deactivation processes regulate $P M N$ responses toward stimulation by TNF as well is unknown.

In confirming previous reports, we found TNF-induced responses in PMN to be highly dependent upon the incubation conditions: whereas PMN in suspension showed only little degranulation and activity of their respiratory burst upon stimulation with TNF, TNF was a most effective stimulus in adherent granulocytes. However, this effect was largely suppressed when cells were preincubated with TNF in suspension

desarginated; DAG, diacylglycerol; HIP, heat-inactivated plasma; HMPS, hexose monophosphate shunt; PAF, platelet-activating factor; TC, transcobalamine (vitamin $B_{12}$ binding protein); TNF, tumor necrosis factor. 
before receiving a secondary dose of TNF under adherent conditions (deactivation). Similarly, preexposure of granulocytes to various PMN stimuli also led to a reduction of TNFinduced cellular functions (cross-deactivation). Both deactivation and cross-deactivation were specific and correlated with down-regulation of the number of TNF receptors.

\section{Methods}

Compounds and reagents. Recombinant TNF was the generous gift of Dr. Frickel, Knoll/BASF AG, Ludwigshafen, Federal Republic of Germany. Recombinant TNF had a specific activity of $3.9 \times 10^{7} \mathrm{U} / \mathrm{mg}$ (cytotoxicity assay on murine L929 cells) and was free of endotoxin as determined by Limulus assay performed by the manufacturer. The preparation appeared as a single band at $17,000 \mathrm{~mol} \mathrm{wt}$ in silver-stains of SDS-PAGE gels. Endotoxin strain R595 Salmonella minnesota, prepared according to the method of Galanos reported by Dahinden et al. (25), was purchased from SEBAK GmbH, Aidenbach, Federal Republic of Germany. FMLP was purchased from Bachem AG, Bubendorf, Switzerland. The tripeptide was dissolved in dimethyl sulfoxide (DMSO) and diluted in $\mathrm{NaCl} 0.15 \mathrm{M}$. Phorbol myristate acetate (PMA, Sigma Chemical Co., St. Louis, MO) was dissolved in DMSO and added to the reaction sample to give a dilution $>1: 1,000$. 1-0 alkyl-2-acetyl-sn-glycerol-3 phosphatidylcholine (platelet-activating factor, PAF) was obtained from Bachem AG. Bioactivity of leuko-

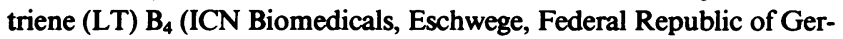
many) was always checked in a chemotaxis assay. Complement component fragment 5a (C5a) was purified from human serum by the procedure of Fernandez and Hugli (26), with minor modifications. These modifications included the substitution of carboxymethyl-Sepharose for carboxymethyl-cellulose, the use of continuous gradients on all ion-exchange columns, and use of the potent serum carboxypeptidase inhibitor described by Ondetti et al. (27). Actinomycin D, cytochalasin B, cycloheximide, chloroquine, colchicine, monensin, and polymyxin B were from Sigma Chemical Co. Pertussis toxin was from List Biological Laboratories, Inc., Campbell, CA.

Monoclonal antibody (MAb) Mon 5005 (clone TNF2, IgG1) and polyclonal antibody PS30 (rabbit), both directed against human TNF, were purchased from Sanbio, Uden, The Netherlands. All other reagents were of analytical grade.

Iodination of TNF. Iodination was performed using the Iodogen procedure with slight modifications (28). $100 \mu \mathrm{l}$ of $\mathrm{Na}^{125} \mathrm{I}$ in phosphate buffer, $0.1 \mathrm{M}$, was added to an Iodogen-coated $(2 \mu \mathrm{g})$ reaction tube (Treff AG, Degersheim, Switzerland) on ice and left to react for $10 \mathrm{~min}$ at $4^{\circ} \mathrm{C}$. Subsequently, the solution was transferred to a second reaction tube containing $20 \mu \mathrm{g}$ of TNF in $10 \mu \mathrm{l}$ of PBS and the iodination was allowed to proceed for $10 \mathrm{~min}$ at $4^{\circ} \mathrm{C}$, when it was stopped by the addition of $1 \mathrm{ml}$ of ice-cold PBS. The iodinated protein was separated from free iodine by filtration over a PD 10 (Sephadex G-25M, Pharmacia, Uppsala, Sweden) column that had been equilibrated with PBS-A. Specific activity of ${ }^{125}$ I-TNF was first estimated by the yield of the iodination procedure and subsequently determined more accurately by self-displacement analysis (29), which, in addition, provided evidence for the similar affinity of iodinated and unlabeled TNF for its receptor (data not shown). Calculations were corrected for the portion of radiolabeled TNF (18-30\%) that did not bind to its receptor as estimated by extrapolation of the binding curve of a constant concentration of ${ }^{125} \mathrm{I}-\mathrm{TNF}(0.1 \mathrm{ng} / \mathrm{ml})$ to an increasing concentration of cells $\left(1-20 \times 10^{6} / \mathrm{ml}\right.$ [30]). Three independent iodinations yielded specific activities between 23.8 and $34.2 \mu \mathrm{Ci} / \mu \mathrm{g}$ and iodinated TNF that was biologically fully active as determined by PMN adhesion assay (see below). ${ }^{125} \mathrm{I}-\mathrm{TNF}$ was stable over at least $8 \mathrm{wk}$, when stored at $-70^{\circ} \mathrm{C}$. Autoradiography of radioiodinated TNF on SDS-PAGE gels showed a single band at 17,000 mol wt. Fractionation of both unlabeled TNF and of ${ }^{125} \mathrm{I}$-TNF by gel filtration chromatography (Sephadex G 75) provided a single peak with an apparent molecular weight of $\approx 53,000$, suggesting a noncovalent trimer as the form in which the glycoprotein occurs under nondenaturating conditions $(19,31)$. Therefore, for calculations of receptor binding data and molarity, a molecular mass of $51 \mathrm{kD}$ was assumed.

Preparation of neutrophils. Venous blood from healthy human volunteers was collected into $60-\mathrm{ml}$ syringes containing preservative-free sodium heparin ( $50 \mathrm{U} / \mathrm{ml}$ blood, Novo Industries, Copenhagen, Denmark) and PMN were separated as described ( $>98 \%$ neutrophils [25]). Incubation medium consisted of autologous heat-inactivated plasma $\left(40 \mathrm{~min}, 56^{\circ} \mathrm{C}\right.$; HIP) prepared from heparinized venous blood $(3$ $\mathrm{U} / \mathrm{ml}$ ). When necessary, PMN were washed in PBS, pH 7.4, supplemented with albumin (ORHA 20/21, Behringwerke AG, Marburg, Federal Republic of Germany) and glucose (138 mM NaCl, $2.7 \mathrm{mM}$ $\mathrm{KCl}, 8.1 \mathrm{mM} \mathrm{Na} \mathrm{HPO}_{4} \cdot 2 \mathrm{H}_{2} \mathrm{O}, 1.5 \mathrm{mM} \mathrm{KH} \mathrm{KO}_{4}, 0.6 \mathrm{mM}$ $\mathrm{CaCl}_{2} \cdot 2 \mathrm{H}_{2} \mathrm{O}, 1.0 \mathrm{mM} \mathrm{MgCl}{ }_{2} \cdot 6 \mathrm{H}_{2} \mathrm{O}, 2.7 \mathrm{mM}$ glucose, $5 \mathrm{mg} / \mathrm{ml}$ albumin; PBS-A).

Equilibrium specific binding of ${ }^{125} I-T N F$ to PMN. PMN in $1 \mathrm{ml}$ of HIP were incubated at $4^{\circ} \mathrm{C}$ in triplicates with increasing concentrations of ${ }^{125} \mathrm{I}-\mathrm{TNF}$ (between $600 \mathrm{pg} / \mathrm{ml}$ and $10 \mathrm{ng} / \mathrm{ml}$, if not indicated otherwise) in reaction tubes and vortexed gently at regular intervals. To terminate the assay and separate PMN-bound ${ }^{125}$ I-TNF from unbound ligand, $850 \mu \mathrm{l}$ of the cell suspension was laid over $500 \mu \mathrm{l}$ of Dextran-T70 (Pharmacia, 10\%, wt/vol in PBS) and centrifuged at $13,000 \mathrm{~g}, 4^{\circ} \mathrm{C}$. This procedure allows separation of bound from unbound ligand within seconds. Reaction tubes were then frozen in an isopropanol bath on dry ice, tips containing the cell pellet were cut off, and radioactivity was quantitated in a $\gamma$-counter (Cobra model 5005, Packard Instrument Co., Inc., Downers Grove, IL) with automatic half-time correction and a counting efficiency of $80 \%$. The assay was found to be linear between $1 \times 10^{6}$ and $1 \times 10^{7} \mathrm{PMN} / \mathrm{ml}$, when a concentration of $600 \mathrm{pg} / \mathrm{ml}^{125} \mathrm{I}$-TNF was used $(r=0.986, P \leq 0.0001)$. In standard assays, a cellular concentration of $5 \times 10^{6} \mathrm{PMN} / \mathrm{ml}$ was used to provide for sufficient accuracy at the given specific activity of radioiodinated TNF and yet keep the total receptor concentration smaller than the $K_{d}$ of the receptor $\left(\left[R_{\mathrm{T}}\right]<K_{\mathrm{d}}[32]\right)$. Nonspecific binding was determined in parallel in duplicates by adding a 100 -fold excess of unlabeled TNF to a second set of matched reaction tubes. Specific binding was defined as the difference between total binding and nonspecific binding, which was consistently $<10 \%$ of total binding.

Adherence and suspension assays. PMN adhesiveness was tested as outlined $(25,33)$, with slight modifications as to the quantification of adherent neutrophils. Briefly, 1-ml aliquots of neutrophil suspensions $\left(4.0 \times 10^{6} \mathrm{PMN} / \mathrm{ml}\right)$ were incubated in $10 \times 35-\mathrm{mm}$ Petri dishes (Falcon Labware, Becton, Dickinson \& Co., Oxnard, CA) for $40 \mathrm{~min}$ at $37^{\circ} \mathrm{C}, 100 \%$ humidity $/ 5 \% \mathrm{CO}_{2}$. Immediately before plating, the adhesion stimulus was added; dilution by stimulus solution was $1 \%$ (vol/ vol). After incubation, the dishes were washed thoroughly and nonadherent PMN were removed by passing the dishes three times through an air-fluid interface sequentially in four beakers containing $\mathrm{NaCl}$ $(0.15 \mathrm{M})$ at room temperature. The dishes were decanted and rest fluid was dried. $1 \mathrm{ml}$ of Zap-oglobin (Coulter Electronics Ltd., Luton, England) was added to each dish and the nuclei, which were set free by the detergent counted in a Coulter flow cytometer (Model $\mathrm{ZB}_{1}$ ) in an adaptation of the method of Nagakawara and Nathan (34). Quantifcation of adherence, induced by various stimulants including FMLP, endotoxin, PMA, and TNF and expressed as the percentage adherent of totally added cells, correlated well with results obtained with ${ }^{111}$ Inlabeled PMN $(r=0.994, P \leq 0.0001$ [9]). All adherence experiments were verified by phase-contrast microscopy.

In degranulation experiments with cells held in suspension, PMN were incubated in overhead rotation (4-6 rpm; multi-purpose rotator model 151, Scientific Industries, Inc., Bohemia, NY) in polypropylene tubes (Falcon Labware) under otherwise identical conditions as used for the adhesion experiments.

Granule exocytosis. Transcobalamine (vitamine $\mathrm{B}_{12}$ binding protein; TC), an excellent indicator of secondary granule exocytosis, which we measured by the relative absorption of ${ }^{57} \mathrm{Co}-\mathrm{B}_{12}(35)$, was determined in supernatants of PMN stimulated to adherence on plas- 
tic dishes and of PMN held in suspension after pelleting the cells by centrifugation at $400 \mathrm{~g}, 4^{\circ} \mathrm{C}$.

Glucose oxidation via the hexose monophosphate shunt (HMPS) Glucose oxidation via the HMPS, which yields NADPH necessary for the formation of oxygen radicals during the respiratory burst and thus serves to quantify the activity of the respiratory burst, was determined by measuring the generation of ${ }^{14} \mathrm{CO}_{2}$ from $\left[1-{ }^{14} \mathrm{C}\right]$ glucose as described (25). Cells were assayed either in suspension (dishes shaken on a IKAVibrax [VXR7, IKA, Staufen, Federal Republic of Germany] at 600 rpm) or under adherent conditions.

Superoxide release. Superoxide release was determined by measuring superoxide dismutase $(10 \mu \mathrm{g} / \mathrm{ml}$, Sigma Chemical Co.) inhibitable cytochrome $c(80 \mu \mathrm{M}$, horse heart type VI, Sigma Chemical Co.) reduction in a dual-wavelength spectrophotometer (model UV 160, Shimadzu, Seisakusho Ltd., Kyoto, Japan) at $550-\mathrm{nm}$ wavelength, $\epsilon$ $=21.6 \mathrm{mM}^{-1}(36,37)$.

\section{Results}

TNF is a potent stimulus of PMN function. TNF increased PMN adhesiveness in a dose-dependent manner (Fig. 1). PMN
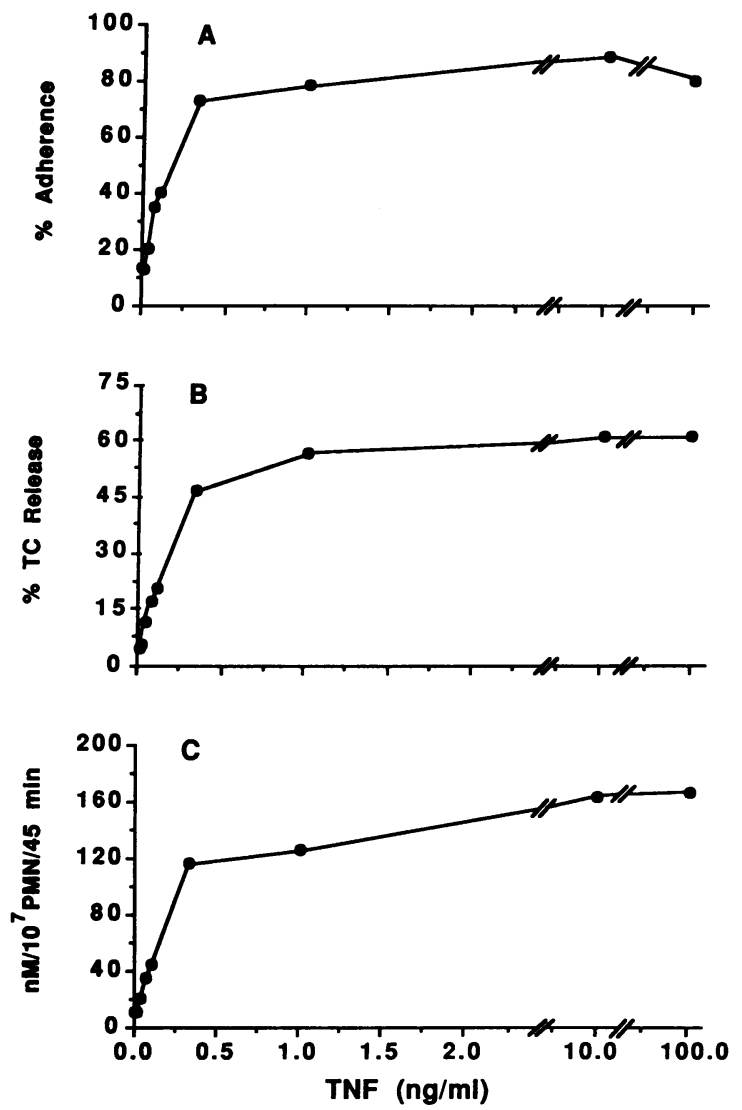

Figure 1. TNF-induced functions in PMN are dose dependent. PMN were incubated with increasing concentrations of TNF for adherence on HIP-coated plastic dishes $\left(40 \mathrm{~min}, 37^{\circ} \mathrm{C}, 5 \% \mathrm{CO}_{2}\right)$. (A) PMN adherent after four sequential washes in $0.15 \mathrm{M} \mathrm{NaCl}$ were quantitated by counting their detergent-released nuclei, and adherence was expressed as percent of the number of totally added cells. $(B)$ TC release, as an indicator of secondary granule exocytosis, was determined by the relative absorption of $\left[{ }^{57} \mathrm{Co}\right] \mathrm{B}_{12}$ in the supernatants after pelleting contaminating cells. $(C)$ Determination of ${ }^{14} \mathrm{CO}_{2}$ formed in the HMPS by oxidation of $\left[1-{ }^{14} \mathrm{C}\right]$ glucose was used to quantify respiratory burst activity. Mean \pm SD of triplicates are shown (SD is shown only when greater than symbol). Three independent experiments gave similar results. responded to as little as $33 \mathrm{pg} / \mathrm{ml}(0.6 \mathrm{pM}) \mathrm{TNF}$ and showed maximal responses at $1 \mathrm{ng} / \mathrm{ml}(20 \mathrm{pM})$, with an $E_{50}$ of $135 \pm 41 \mathrm{pg} / \mathrm{ml}(2.6 \pm 0.8 \mathrm{pM}, n=3)$. Under adherent conditions, cells were induced by TNF to degranulate $\left(E_{50}\right.$ $=200 \pm 28 \mathrm{pg} / \mathrm{ml}[3.9 \pm 0.6 \mathrm{pM}], n=3)$ and to activate their respiratory burst $\left(\mathrm{ED}_{50}=164 \pm 80 \mathrm{pg} / \mathrm{ml}[3.2 \pm 1.5 \mathrm{pM}], n=3\right)$ to an extent comparable with that of PMA $(100 \mathrm{ng} / \mathrm{ml}$; see Figs. 3 and 4 below). However, when PMN were stimulated in suspension under otherwise identical conditions as under adherence, only slight increases in exocytosis or HMPS activity could be elicited even at concentrations of TNF up to 100 $\mathrm{ng} / \mathrm{ml}$ (Fig. 2). Similar results were obtained for $\mathrm{O}_{2}^{-}$release: PMN (adherent) $0.43 \pm 0.86 \mathrm{nmol} / 10^{6} \mathrm{PMN}$ per $30 \mathrm{~min}$; PMN (in suspension), $0.10 \pm 1.72 \mathrm{nmol} / 10^{6} \mathrm{PMN}$ per $30 \mathrm{~min}$; $P M N$ plus TNF (10 ng/ml; adherent), $8.06 \pm 1.82 \mathrm{nmol} / 10^{6} \mathrm{PMN}$ per $30 \mathrm{~min}$; PMN plus TNF (in suspension), $0.33 \pm 0.40 \mathrm{nmol} / 10^{6}$ $\mathrm{PMN}$ per 30 min (mean \pm SD of triplicates, $n=3$ ).

In contrast to PMN activation by FMLP (38), TNF-induced cellular responses were insensitive to pertussis toxin as preincubation $\left(37^{\circ} \mathrm{C}, 2 \mathrm{~h}\right)$ with pertussis toxin $(1 \mu \mathrm{g} / \mathrm{ml})$ revealed the following inhibition profile (percent reduction compared to control cells): FMLP (adhesion), 87.1 $16.0 \%$; FMLP (TC release), 89.3 $\pm 4.2 \%$; PMA (adhesion), 8.3 $\pm 6.6 \%$; PMA (TC release), 2.4 $2.3 \%$; TNF (adhesion), 9.4 $\pm 7.4 \%$; TNF (TC release), $6.9 \pm 1.1 \%$.

Remarkably, TNF (10 ng/ml)-induced release of transcobalamine, both in adhesion and in suspension, was unaltered by pre- and coincubation of PMN with $5 \mu \mathrm{g} / \mathrm{ml}$ cytochalasin B: adhesion (without cytochalasin B), $80.6 \%$; (with cytochala-
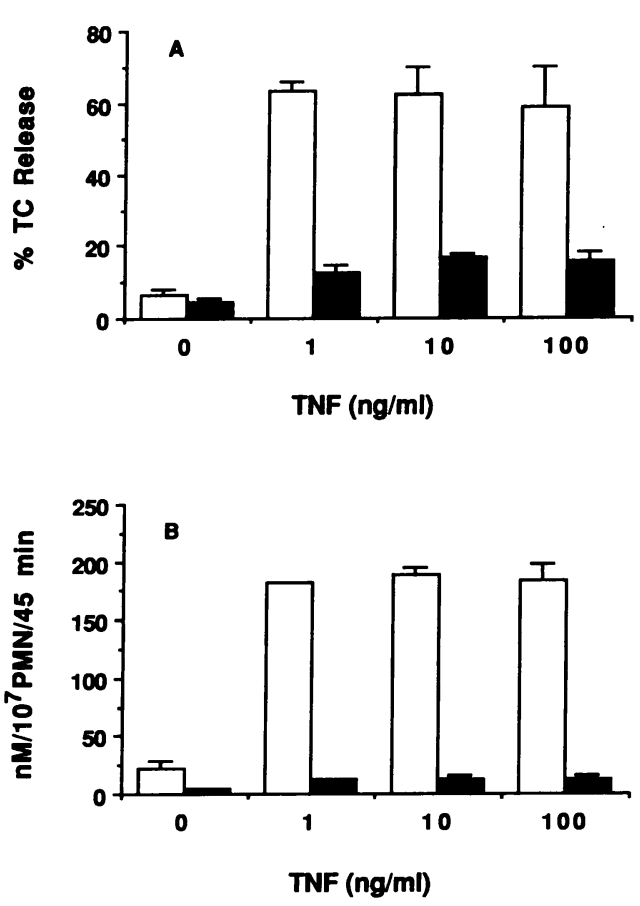

Figure 2. TNF-induced cellular responses depend upon PMN adherence. PMN in HIP were stimulated by TNF and incubated for $\mathbf{4 0}$ min, $37^{\circ} \mathrm{C}$ either under adherent conditions (open bars) or in suspension (gray bars). At the end of the incubation period $(A)$ TC release and $(B)$ HMPS activity were determined as described for Fig. 1. Bars denote mean \pm SD of triplicates (SD is shown only when greater than symbol). Three independent experiments gave similar results. 
sin B), 77.7\%; suspension (without cytochalasin B), $14.0 \%$; (with cytochalasin B), 16.8\%.

Endotoxin contamination, as the source of the observed effects, was ruled out by experiments, in which PMN were stimulated by TNF $(10 \mathrm{ng} / \mathrm{ml})$, pretreated either at $100^{\circ} \mathrm{C}, 30$ min (79.9\% inhibition of adhesion, compared to controls) or with polymyxin B $(10 \mu \mathrm{g} / \mathrm{ml}, 3.7 \%$ inhibition).

Deactivation and cross-deactivation of TNF-induced responses in PMN. Because TNF proved to be such a powerful activator of PMN function under adherent conditions, while inducing only little functional activity as long as cells were held in suspension, we proceeded to investigate whether preexposure of PMN to TNF in suspension might influence their responses under adherent conditions toward a second dose of TNF, and we found that preincubation of PMN in suspension resulted in a dose-dependent inhibition. of adherence, degranulation, and HMPS activity (Fig. 3) as well as superoxide production induced under adherent conditions by a second dose
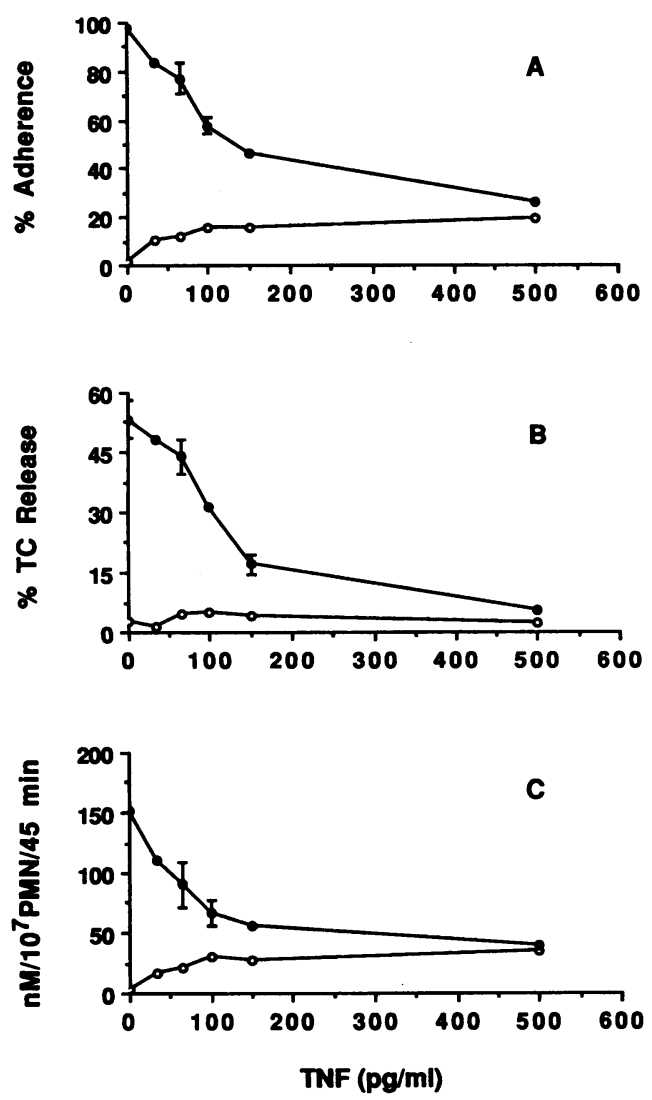

Figure 3. Deactivation of TNF-induced responses by preexposure of PMN to TNF in suspension. PMN in HIP were incubated with increasing concentrations of TNF in suspension $\left(2 \mathrm{~h}, 37^{\circ} \mathrm{C}\right)$, subsequently either restimulated by TNF $(10 \mathrm{ng} / \mathrm{ml}, \bullet)$, or not (o), and let to adhere $\left(40 \mathrm{~min}, 37^{\circ} \mathrm{C}, 5 \% \mathrm{CO}_{2}\right)$. $(A)$ Adherence, $(B) \mathrm{TC}$ release, and $(C)$ HMPS activity were determined as described for Fig. 1. Control cells restimulated by PMA $(100 \mathrm{ng} / \mathrm{ml})$ instead of TNF were fully responsive: adherence (99.2/98.5\%), TC release (59.3/52.9\%), and HMPS (310.8/302.8 $\mathrm{nM} / 10^{7} \mathrm{PMN}$ per $45 \mathrm{~min}$, where the first value corresponds to cells preincubated without TNF, the second value to cells preincubated with $500 \mathrm{pg} / \mathrm{ml}$ TNF). Results depicted in $A$ and $B$ are from the same experiment. Mean $\pm 1 / 2$ range of duplicates (shown only when greater than symbol) are shown. Three independent experiments (each panel) yielded similar results. of $10 \mathrm{ng} / \mathrm{ml}$ TNF: preincubation without TNF-without secondary TNF, $1.24 \pm 0.37 \mathrm{nmol} / 10^{6} \mathrm{PMN}$ per $30 \mathrm{~min}$; with secondary TNF $(10 \mathrm{ng} / \mathrm{ml}), 8.56 \pm 1.99 \mathrm{nmol} / 10^{6} \mathrm{PMN}$ per 30 min; preincubation with TNF $(500 \mathrm{pg} / \mathrm{ml})$-without secondary TNF, $2.73 \pm 1.10 \mathrm{nmol} / 10^{6} \mathrm{PMN}$ per $30 \mathrm{~min}$; with secondary TNF $(10 \mathrm{ng} / \mathrm{ml}) ; 4.32 \pm 0.58 \mathrm{nmol} / 10^{6} \mathrm{PMN}$ per $\left.30 \mathrm{~min}\right)$. It should be noticed, that the activity due to secondary TNF was regarded as the difference between total response (prestimulating TNF plus secondary TNF) and the response evoked by the prestimulating dose alone. Inhibition (optimal after $2 \mathrm{~h}$ of preincubation) was specific, as PMN were fully vital ( $98 \%$ by trypan blue) and showed undiminished responses, when PMA $(100 \mathrm{ng} / \mathrm{ml}$, Fig. 3) or FMLP $(2.5 \mu \mathrm{M}$, not shown) were used as second stimuli. In other words, deactivation exists for TNF as well as it does for FMLP. Probably owing to secondary metabolic changes, PMN, which had been preincubated and not restimulated by TNF, showed reduced functional responses under adherent conditions compared with cells, which were incubated for adhesion immediately after addition of the stimulus (compare Figs. 1 and 3).

Surprisingly, preincubation of granulocytes with stimuli other than TNF resulted also in a specific, dose-dependent desensitization toward secondary stimulation by TNF with respect to adherence, degranulation, HMPS activity (Fig. 4), and superoxide release (preincubation without LPS - without secondary TNF, $1.28 \pm 0.26 \mathrm{nmol} / 10^{6} \mathrm{PMN}$ per $30 \mathrm{~min}$; with secondary TNF $(10 \mathrm{ng} / \mathrm{ml}), 4.80 \pm 0.38 \mathrm{nmol} / 10^{6} \mathrm{PMN}$ per 30 min; preincubation with LPS $(40 \mathrm{ng} / \mathrm{ml})$-without secondary TNF, $2.46 \pm 0.31 \mathrm{nmol} / 10^{6} \mathrm{PMN}$ per $30 \mathrm{~min}$; with secondary TNF (10 ng/ml), $3.62 \pm 0.10 \mathrm{nmol} / 10^{6} \mathrm{PMN}$ per $30 \mathrm{~min}$ ). Again, it must be emphasized that the response due to the secondarily added TNF is equivalent to the difference between the total response (prestimulus plus secondary TNF) and the response elicited by the prestimulus alone. In the case of endotoxin, this response elicited by the prestimulus alone was generally greater at maximally deactivating doses than with TNF (Figs. 4 and 5). In the experiment depicted in Fig. $4 C$, cellular activity due to secondary TNF approximated zero, whereas in other experiments (Fig. 4, $A$ and $B$ ) a considerable rest activity remained. In contrast to these at least partly donor-specific variations in the degree of cross-deactivation, particularly in the case of endotoxin and FMLP, the degree of tachyphyllaxis caused by TNF itself varied only little between experiments. Stimuli so different in origin, chemical structure, and pattern of biological functions as $\mathrm{LTB}_{4}, \mathrm{C} 5 \mathrm{a}, \mathrm{C} 5 \mathrm{a}$ desarg, endotoxin, and FMLP caused specific cross-deactivation to TNF (Fig. 5).

In contrast, preincubation with PMA $(5 \mathrm{ng} / \mathrm{ml})$, a direct activator of protein kinase $C$, was without effect, indicating that deactivation and cross-deactivation of TNF-induced responses in human granulocytes are not mediated by protein kinase C (Fig. 5). This concentration of PMA was chosen, because $5 \mathrm{ng} / \mathrm{ml}$ PMA stimulates PMN adhesion, degranulation, and respiratory burst, whereas heavy aggregation, which is common with higher concentrations of PMA, is avoided.

Characterization of high-affinity binding sites for TNF on neutrophils. Before the question could be addressed, whether alterations in receptor-ligand binding might be responsible for deactivation and cross-deactivation, high-affinity binding of TNF to PMN in our system had to be characterized (Fig. 6). At $37^{\circ} \mathrm{C},{ }^{125} \mathrm{I}-\mathrm{TNF}$ binding to PMN peaked early $(10 \mathrm{~min})$ to decrease relatively fast thereafter, whether azide $(0.1 \%)$ had 

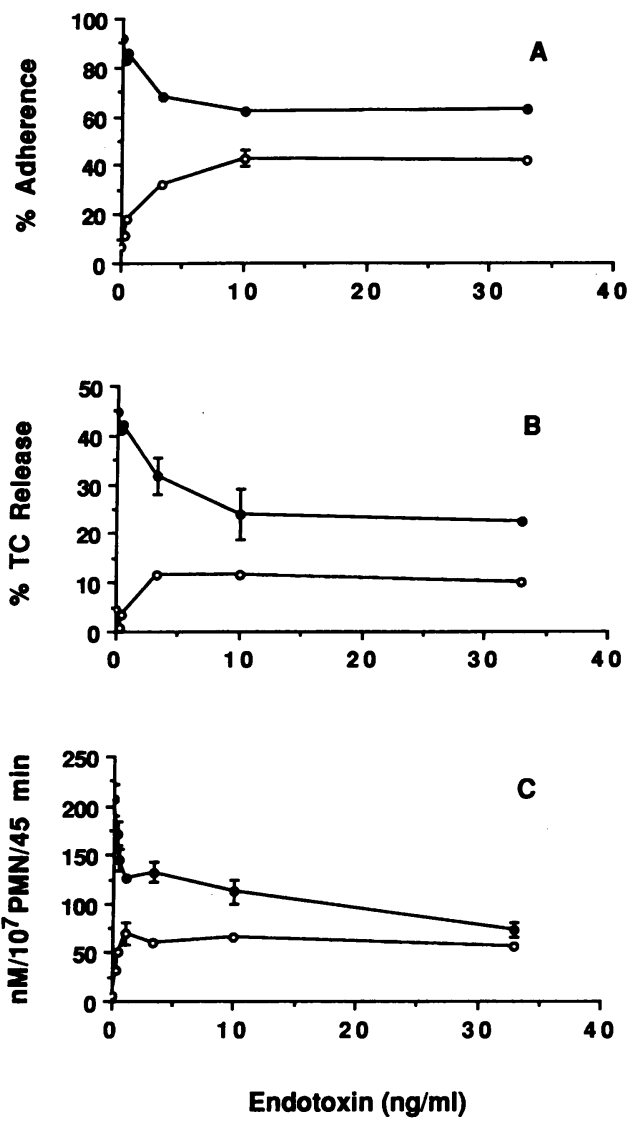

Figure 4. Cross-deactivation of TNF-induced responses by preexposure of PMN to endotoxin in suspension. PMN in HIP were incubated with increasing concentrations of endotoxin in suspension ( 2 h, $\left.37^{\circ} \mathrm{C}\right)$, subsequently either restimulated by TNF $(10 \mathrm{ng} / \mathrm{ml}, \bullet)$, or not (O), and let to adhere $\left(40 \mathrm{~min}, 37^{\circ} \mathrm{C}, 5 \% \mathrm{CO}_{2}\right)$. $(A)$ Adherence, $(B)$ TC release, and $(C)$ HMPS activity were determined as described under Fig. 1. Control cells restimulated by PMA $(100 \mathrm{ng} / \mathrm{ml})$ instead of TNF were fully responsive: adherence (97.5/99.1\%), TC release (54.9/62.2\%), and HMPS (295.4/319.7 $\mathrm{nM} / 10^{7} \mathrm{PMN}$ per $\left.45 \mathrm{~min}\right)$, where the first value corresponds to cells preincubated without endotoxin, the second value to cells preincubated with $33 \mathrm{ng} / \mathrm{ml}$ endotoxin). Results depicted in $A$ and $B$ are from the same experiment. Mean $\pm 1 / 2$ range of duplicates $(A$ and $B$ ), or mean \pm SD of triplicates $(C)$ are shown. Three independent experiments (each panel) gave similar results.

been added to the cell suspension or not (Fig. $6 \mathrm{~A}$ ). At $37^{\circ} \mathrm{C}$ ${ }^{125}$ I-TNF bound to its receptor appears to be rapidly internalized and then intracellularly degraded at a steady rate: PMN incubated at $4^{\circ} \mathrm{C}$ for $2 \mathrm{~h}$ showed only little ${ }^{125} \mathrm{I}-\mathrm{TNF}$ binding, which could not be dissociated by low pH (Fig. $6 B[31,39]$ ), and hence had to be regarded as internalized. When cells that had ${ }^{125} \mathrm{I}$-TNF bound to their cell surface receptors at $4^{\circ} \mathrm{C}$ were reincubated after three washes (PBS-A) in HIP at $37^{\circ} \mathrm{C}$, surface-bound ${ }^{125} \mathrm{I}-\mathrm{TNF}$ was rapidly internalized and hence was no longer dissociable at low pH (Fig. $6 \mathrm{~B}$ ). Furthermore, when PMN that were preincubated with ${ }^{125} \mathrm{I}-\mathrm{TNF}$ at $37^{\circ} \mathrm{C}$ for 60 min were reincubated after three washes (PBS-A) in HIP at $37^{\circ} \mathrm{C}$, concomitant with the gradual decrease of PMN-associated radioactivity, an increase in radioactivity in the supernatant could be detected, most of which was non-TCA-precipitable (Fig. $6 C$ ). Taken together, these results suggest that at $37^{\circ} \mathrm{C} \mathrm{PMN}$ internalize ${ }^{125} \mathrm{I}-\mathrm{TNF}$ via its receptor and degrade it
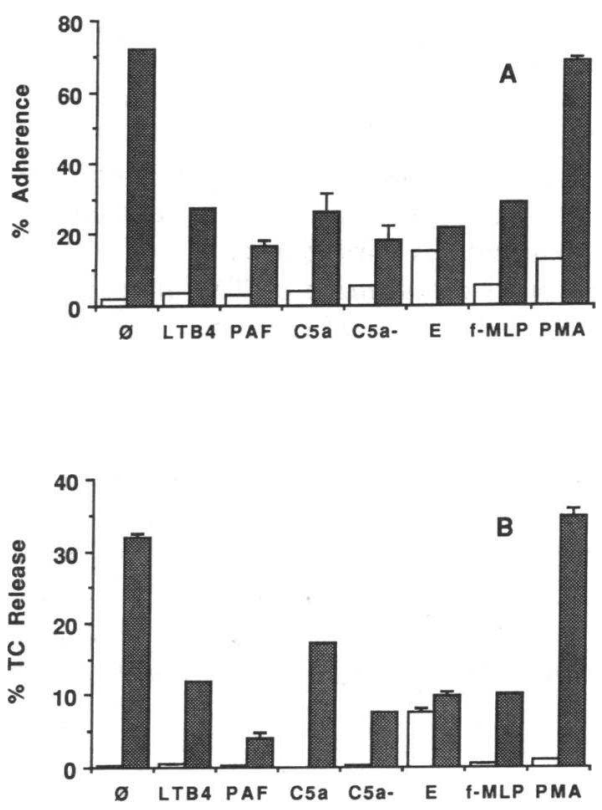

Figure 5. Cross-deactivation of TNF-induced functions in PMN by various stimuli. PMN in HIP (Ø) were stimulated by $\mathrm{LTB}_{4}(250$ $\mathrm{ng} / \mathrm{ml}), \mathrm{C} 5 \mathrm{a}(250 \mathrm{ng} / \mathrm{ml}), \mathrm{C} 5 \mathrm{a}-(\mathrm{C} 5 \mathrm{a}$ desarg, $250 \mathrm{ng} / \mathrm{ml})$, endotoxin $(\mathrm{E}, 40 \mathrm{ng} / \mathrm{ml})$, FMLP $(0.1 \mu \mathrm{M})$, or PMA $(5 \mathrm{ng} / \mathrm{ml})$ and incubated in suspension $\left(2 \mathrm{~h}, 37^{\circ} \mathrm{C}\right)$. Subsequently cells were restimulated by TNF $(10 \mathrm{ng} / \mathrm{ml}$, gray bars) or not (white bars) and let to adhere (40 min, $\left.37^{\circ} \mathrm{C}, 5 \% \mathrm{CO}_{2}\right)$. $(A)$ Adherence and $(B)$ transcobalamine release were determined as described for Fig. 1. Control cells restimulated by PMA $(100 \mathrm{ng} / \mathrm{ml})$ instead of TNF were fully responsive (not shown). Values depicted in $A$ and $B$ are from the same experiment. Bars denote mean $\pm 1 / 2$ range of duplicates (only shown when greater than symbol). Three independent experiments gave similar results.

thereafter. They explain the rapid rise and gradual decline of cell-associated radioactivity when cells are incubated with ${ }^{125} \mathrm{I}$ TNF at $37^{\circ} \mathrm{C}$ (Fig. $6 \mathrm{~A}$ ).

In contrast to incubations at $37^{\circ} \mathrm{C}$, binding at $4^{\circ} \mathrm{C}$ reached equilibrium after $8 \mathrm{~h}$ (Figs. 6 and 7). Consequently, these conditions were used for all receptor binding studies. The $K_{\text {off }}$ at $4^{\circ} \mathrm{C}$ was remarkably low, so that after three washes (PBS-A) over $45 \mathrm{~min}$, only little dissociation of ${ }^{125} \mathrm{I}$-TNF from PMN could be detected (Fig. $7 \mathrm{~A}$ ). Moreover, the rate of dissociation was hardly influenced by the addition of a 100 -fold excess of unlabeled TNF (Fig. $7 \mathrm{~A}$ ). The possibility that ${ }^{125} \mathrm{I}$-TNF might become internalized even at $4^{\circ} \mathrm{C}$ was excluded by experiments, which showed that ${ }^{125} \mathrm{I}-\mathrm{TNF}$ bound to PMN at $4^{\circ} \mathrm{C}$ could be dissociated by exposure to low pH ( $98 \%$ vitality, no reduction in cell numbers; Fig. $7 \mathrm{~B}$ ).

In Scatchard plots (40) of saturation binding experiments, carried out under the conditions described above, only a single class of TNF receptors could be detected on PMN: receptor number $(\mathrm{N})=516 \pm 94 ; n=28$ (iodination $1,557 \pm 90[n=9]$; iodination 2,522 $\pm 80[n=14]$; iodination 3,426 $n 91[n=5]$ ), $K_{d}=11.7 \pm 2.9 \mathrm{pM} ; n=28$ ). When receptor assays were performed in PBS-A similar values were obtained $(N=637 \pm 54$; $K_{\mathrm{d}}=9.3 \pm 0.1 \mathrm{pM} ; n=2$, figures denote mean $\pm 1 / 2$ range).

Deactivation and cross-deactivation of PMN toward TNF are correlated to a reduction in TNF surface receptors. When PMN were preincubated with TNF or FMLP in exactly the 

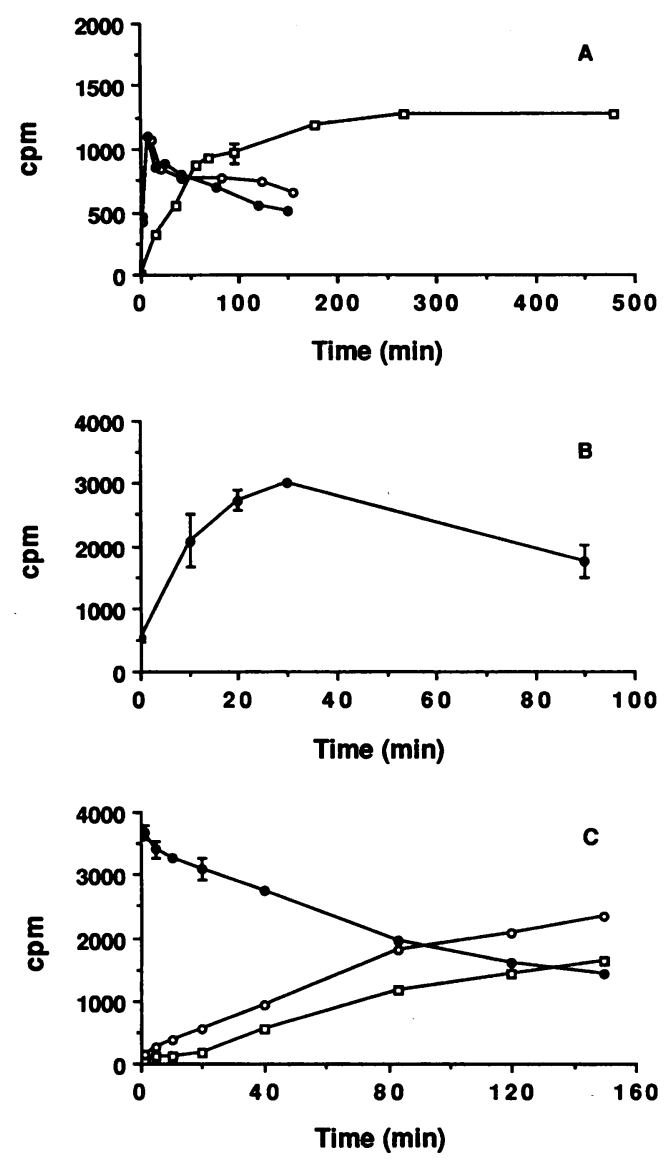

Figure 6. ${ }^{125} \mathrm{I}-\mathrm{TNF}$ binding to PMN under different conditions. $(A)$ PMN in HIP $\left(3 \times 10^{6} / \mathrm{ml}\right)$ were incubated for varying periods of time with ${ }^{125} \mathrm{I}-\mathrm{TNF}(1 \mathrm{ng} / \mathrm{ml})$ at $4^{\circ} \mathrm{C}(0.1 \%$ azide, $\square)$, at $37^{\circ} \mathrm{C}(0.1 \%$ azide, $O$ ) in suspension, or at $37^{\circ} \mathrm{C}$ in suspension without the addition of azide (๑). At the indicated times, triplicate samples were taken, and the receptor assay performed as detailed in Methods. Counts were normalized to $1 \times 10^{6} \mathrm{PMN}$. (B) After incubation in HIP $\left(5.0 \times 10^{6} / \mathrm{ml}\right)$ with ${ }^{125} \mathrm{I}-\mathrm{TNF}(4 \mathrm{ng} / \mathrm{ml})$ for $2 \mathrm{~h}$ at $4^{\circ} \mathrm{C}$ PMN were washed three times with PBS-A, resuspended in HIP, and reincubated at $37^{\circ} \mathrm{C}$. At the indicated times, samples were taken, washed twice in PBS-A, and finally exposed to $\mathrm{pH} 3.0$ (glycine buffer, 50 $\mathrm{mM}$ in $0.1 \mathrm{M} \mathrm{NaCl}$ ) for $3 \mathrm{~min}$ to detach surface bound ligand. After neutralizing $\mathrm{pH}$ by PBS-A dilution cells were pelleted and cell-associated radioactivity was determined as described above. $(C) \mathrm{PMN}$ in HIP $\left(6.3 \times 10^{6} / \mathrm{ml}\right)$ were incubated with ${ }^{125} \mathrm{I}-\mathrm{TNF}(10 \mathrm{ng} / \mathrm{ml})$ in suspension for $60 \mathrm{~min}$ at $37^{\circ} \mathrm{C}$, washed three times in PBS-A, and finally resuspended and reincubated in HIP $\left(2.4 \times 10^{6} / \mathrm{ml}\right)$. At the indicated times, triplicate samples were taken, layered onto Dextran$\mathrm{T} 70(10 \%, \mathrm{wt} / \mathrm{vol})$ in $1.5-\mathrm{ml}$ reaction tubes, and separated by centrifugation. Cell-associated radioactivity (not normalized, $\bullet$ ) was determined as described above. Additionally, after Dextran centrifugation supernatant was taken, and total (O) and non-TCA-precipitable radioactivity $(\square)$ was measured. Values were corrected for different sample volumes. Mean \pm SD of triplicates are shown.

same way as described for functional deactivation and crossdeactivation experiments, and were subsequently examined for equilibrium receptor binding, they showed a strong reduction in the number of TNF receptors together with a concomitant decrease in apparent receptor affinity (Figs. 8 and 9, Table I). Notably, on PMN preincubated with $500 \mathrm{pg} / \mathrm{ml} \mathrm{TNF}$, specific binding was too low to be differentiated from background
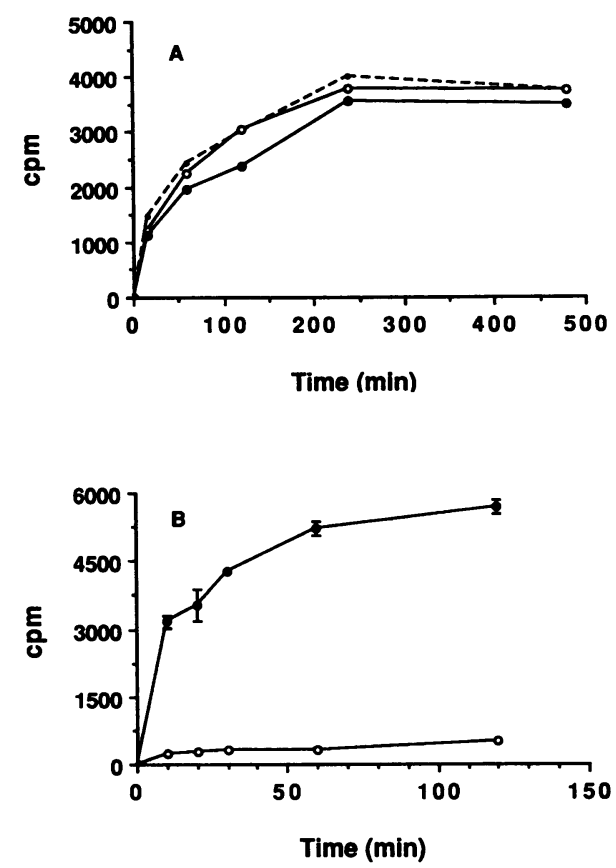

Figure 7. At $4{ }^{\circ} \mathrm{C},{ }^{125} \mathrm{I}-\mathrm{TNF}$ is bound to PMN in a saturable manner, and once bound, is not dissociable by excess unlabeled TNF, but is not internalized. $(A)$ PMN in HIP $\left(6.6 \times 10^{6} / \mathrm{ml}\right)$ were incubated with ${ }^{125} \mathrm{I}-\mathrm{TNF}(1 \mathrm{ng} / \mathrm{ml})$ at $4^{\circ} \mathrm{C}$. At the indicated times, samples were taken and PMN were either directly pelleted through Dextran (total binding, dashed line) or subsequent to a 60 -min exposure to a 100 fold excess of unlabeled TNF ( $\bullet$ ). A third batch was washed three times (PBS-A, O) over 60 min and cell-bound radioactivity was determined as described for Fig. 6. Symbols denote mean of triplicates, normalized to $5 \times 10^{6} \mathrm{PMN}, \mathrm{SD}(<12 \%)$ are not shown for the sake of clarity. Two independent experiments yielded similar results. $(B)$ PMN in HIP $\left(5 \times 10^{6} / \mathrm{ml}\right)$ were incubated with TNF $(4 \mathrm{ng} / \mathrm{ml})$ at $4^{\circ} \mathrm{C}$. At the indicated times, samples were taken, washed twice in PBS-A, and either directly pelleted (๑) or first exposed to pH 3.0 (glycine buffer, $50 \mathrm{mM}$ in $0.1 \mathrm{M} \mathrm{NaCl}, \mathrm{O}$ ) for $3 \mathrm{~min}$. After neutralizing pH by PBS-A dilution, cells were centrifuged and cell-associated radioactivity was determined. Mean \pm SD of triplicates, normalized to 5 $\times 10^{6} \mathrm{PMN}$, are shown. Two independent experiments yielded similar results.

noise. Three cell washes proved to be optimal to remove cold TNF before the equilibrium studies. When stimuli (other than TNF) were added to the controls during the receptor assay, no competition with ${ }^{125}$ I-TNF for the receptor could be detected (not shown).

Preincubation of $\mathrm{PMN}$ at $37^{\circ} \mathrm{C}$, without the addition of stimulus, did not alter TNF receptor expression, when compared to cells held at $4^{\circ} \mathrm{C}$.

The role of calcium, protein kinase $A$, protein kinase $C$, and pertussis toxin-sensitive $G$ proteins in signal transduction leading to TNF-specific deactivation/cross-deactivation of $P M N$. Pertussis toxin inhibited TNF-specific deactivation only with such stimuli as FMLP (Fig. $10 \mathrm{~B}$ ), which cause PMN adhesion, degranulation, or chemotaxis via pertussis toxinsensitive $G$ proteins (38), whereas deactivation by TNF and lipopolysaccharide (LPS), which activate PMN independently from pertussis toxin-sensitive $\mathrm{G}$ proteins (see above), was left uninfluenced (Fig. 10, $A$ and $C$ ). Neither TNF or LPS nor pertussis toxin-sensitive G protein-linked FMLP seemed to 

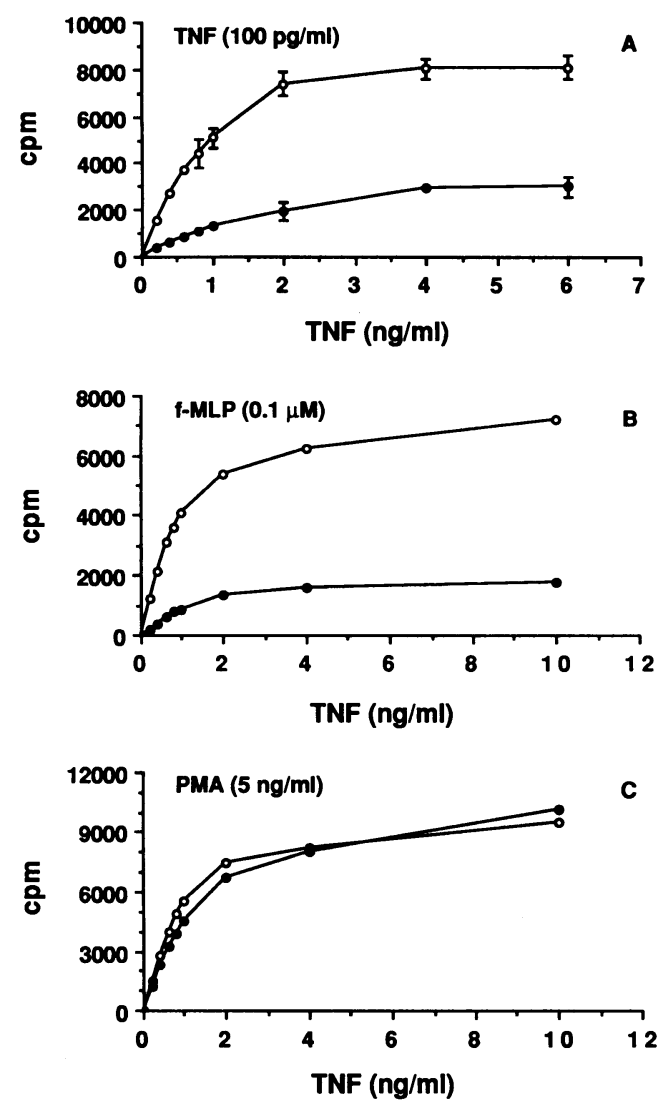

Figure 8. TNF receptor down-regulation caused by preexposure of PMN to TNF and FMLP. After preincubation at $37^{\circ}$ in suspension with $(A)$ TNF $(100 \mathrm{pg} / \mathrm{ml}, \bullet),(B)$ FMLP $(0.1 \mu \mathrm{M}, \bullet)$, or $(C)$ PMA (5 $\mathrm{ng} / \mathrm{ml}, \bullet)$, PMN were either submitted directly $(B$ and $C$ ), or after three washes in PBS-A $(A)$, to the receptor binding assay as described under Fig. $6\left(8 \mathrm{~h}\right.$, in $\mathrm{HIP}$ at $\left.4^{\circ} \mathrm{C}\right)$. In each experiment, unstimulated cells, treated otherwise exactly the same as stimulated cells, were assayed as controls $(O)$. $(A)$ In experiments, where cells had to be washed, results were finally normalized to a cell count of $5 \times 10^{6} / \mathrm{ml}$. Symbols denote mean \pm SD of triplicates (not shown, if smaller than the symbol). Three independent experiments (each panel) yielded similar results. $(B$ and $C$ ) In additional experiments, FMLP or PMA were added to the controls during the receptor assay to exclude direct receptor competition.

cause TNF-specific deactivation via the phospholipase C-dependent generation of diacylglycerol (DAG) and activation of proteinkinase $C$, inasmuch as preincubation of $P M N$ with PMA left both functional responses toward TNF and TNF receptors unaltered (Fig. 5, Table I). Forskolin $\left(10^{-5}\right.$ to $10^{-7}$ M) and isoprenalin, which activate adenylate cyclase either directly or via adrenergic receptors, led to no significant reduction of TNF receptor numbers $(85.9-96 \%$ of original receptor numbers), making protein kinase A unlikely to be the secondary messenger of TNF deactivation. However, preincubation of PMN with the ionophore ionomycin resulted in a dramatic reduction of TNF receptors on the cellular surface (Table I). Testing ionomycin in functional deactivation of PMN was not possible because the ionophore caused by itself $77 \%$ adhesion at $5 \mu \mathrm{M}$ with no response at $1 \mu \mathrm{M}$ (in HIP). It thus appears that changes in granulocyte calcium metabolism might be involved in TNF receptor down-regulation and functional deactivation/cross-deactivation.
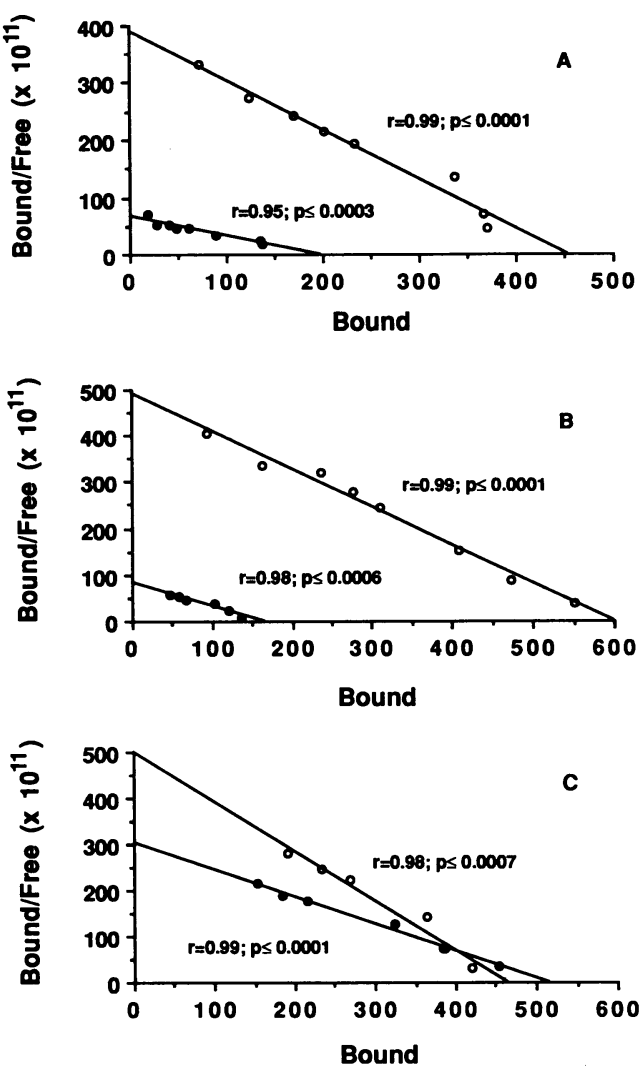

Figure 9. TNF receptor down-regulation caused by preexposure of PMN to TNF and FMLP. Data as depicted in Fig. 8 plotted according to the method of Scatchard. (A) Preincubation with TNF (100 $\mathrm{pg} / \mathrm{ml}, \bullet): N=194, K_{\mathrm{d}}=29.1$; controls (O): $N=454, K_{\mathrm{d}}=11.6 \mathrm{pM}$ pM. (B) Preincubation with FMLP $(0.1 \mu \mathrm{M}, \bullet): N=162, K_{\mathrm{d}}=19.7$ pM; controls (O): $N=598, K_{\mathrm{d}}=12.2 \mathrm{pM}$. (C) Preincubation with PMA (5 ng/ml, $\bullet$ ): $N=521, K_{\mathrm{d}}=17.5 \mathrm{pM}$; controls (O): $N=465$, $K_{\mathrm{d}}=9.3 \mathrm{pM}$.

The degree of deactivation caused by increasing concentrations of TNF correlated well with the degree of receptor down-regulation (Fig. $11 A$ ). Similarly, TNF cross-deactivation due to either LPS (Fig. $11 B)$ or FMLP $(r=0.95)$ was highly correlated to a reduction in TNF receptor number. The functional relevance of this statistical correlation is underscored by the fact that, all stimuli, which caused cross-deactivation of PMN toward TNF, induced a reduction of TNF surface receptors, whereas PMA, which had been without effect in cross-deactivation studies, also failed to down-regulate TNF receptor surface expression (Table I). Moreover, pertussis toxin influenced deactivation or cross-deactivation and TNF receptor numbers always in parallel (Fig. 10).

Possible mechanisms of TNF receptor down-regulation. TNF receptor down-regulation induced by TNF itself can be explained by internalization of the receptor-ligand complex (Fig. 6) and insufficient replacement of receptors either by de novo synthesis or by receptor recycling. The mechanism of TNF receptor reduction due to preincubation with different stimuli such as FMLP and endotoxin, however, was not so straightforward to evaluate.

These stimuli probably do not act through the induction of TNF synthesis in PMN, which in turn might have bound to its receptor, inasmuch as inhibitors of protein synthesis (actino- 
Table I. Down-regulation of TNF Receptors in Response to Preincubation of PMN with Various Stimuli

\begin{tabular}{lcc}
\hline & $N^{*}$ & $K_{d}$ \\
\hline & & $p M$ \\
PAF $\left(1 \times 10^{-4} \mathrm{M}\right)$ & $306 \pm 27$ & $21.9 \pm 4.9$ \\
& $(597 \pm 33)$ & $(11.2 \pm 2.6)$ \\
LTB $_{4}(250 \mathrm{ng} / \mathrm{ml})$ & $384 \pm 75$ & $16.3 \pm 3.2$ \\
& $(516 \pm 19)$ & $(12.4 \pm 2.0)$ \\
C5a $(250 \mathrm{ng} / \mathrm{ml})$ & $363 \pm 61$ & $17.3 \pm 5.0$ \\
& $(521 \pm 58)$ & $(11.4 \pm 3.5)$ \\
C5a desarg $(250 \mathrm{ng} / \mathrm{ml})$ & $156 \pm 21$ & $33.2 \pm 12.8$ \\
& $(510 \pm 62)$ & $(9.8 \pm 0.6)$ \\
FMLP $(100 \mathrm{nM})$ & $167 \pm 6$ & $26.4 \pm 4.9$ \\
& $(555 \pm 114)$ & $(11.7 \pm 0.6)$ \\
Endotoxin $(40 \mathrm{ng} / \mathrm{ml})$ & $222 \pm 76$ & $57.7 \pm 39.4$ \\
& $(565 \pm 117)$ & $(13.0 \pm 1.1)$ \\
TNF $(100 \mathrm{pg} / \mathrm{ml})^{\ddagger}$ & $191 \pm 2$ & $23.6 \pm 4.0$ \\
& $(407 \pm 81)$ & $(13.7 \pm 4.9)$ \\
Ionomycin $\left(1 \times 10^{-5} \mathrm{M}\right)$ & $73 \pm 4$ & $49.4 \pm 0.1$ \\
& $(598 \pm 110)$ & $(14.0 \pm 1.1)$ \\
PMA $(5 \mathrm{ng} / \mathrm{ml})$ & $564 \pm 49$ & $13.9 \pm 2.6$ \\
& $(543 \pm 65)$ & $(9.5 \pm 0.1)$
\end{tabular}

After preincubation in suspension for $2 \mathrm{~h}, \mathrm{PMN}$ were either directly (stimuli other than TNF) or after three washes in PBS-A (TNF) assayed for receptor binding $\left(8 \mathrm{~h}\right.$, in $\mathrm{HIP}$ at $\left.4^{\circ} \mathrm{C}\right)$. In each experiment, unstimulated cells, treated otherwise exactly the same as stimulated cells, served as controls (in parentheses). Cell counts were always checked before incubation with ${ }^{125}$ I-TNF and subsequent calculations corrected accordingly (of importance only when cells had to be washed after preincubations with TNF itself). Number of receptors and $K_{\mathrm{d}}$ were derived from Scatchard plots.

$* N$, number of receptors.

${ }^{\ddagger}$ On PMN preincubated with $500 \mathrm{pg} / \mathrm{ml}$ TNF, specific binding was too low to be differentiated from background noise. Values denote mean \pm SD of three experiments in each set.

mycin D, cycloheximide) did not abolish the down-regulation of receptors (Table II). Furthermore, pretreatment of TNF $(100 \mathrm{pg} / \mathrm{ml})$, but not of FMLP (10 nM), with anti-TNF-directed MAbs Mon 5005 (2:1) reversed receptor down-regulation (control, 2,739 $\pm 222 \mathrm{cpm}$; TNF alone, $841 \pm 101 \mathrm{cpm}$; TNF with MAb, 2,476 $\pm 112 \mathrm{cpm}$; FMLP alone, $467 \pm 27 \mathrm{cpm}$; FMLP with MAb, $311 \pm 50 \mathrm{cpm}$; mean \pm SD of triplicates).

The possibility that TNF receptors were enzymatically cleaved by proteases set free from activated granulocytes was tested by preincubating cells with the filtrate of sonicationlysed PMN at a concentration of lysosomal proteases equivalent to $10 \%$ of total cellular contents. This free concentration of lysosomal contents, which is higher than any concentration induced by the relevant stimuli in suspension, did not alter TNF receptor expression at all $(102.9 \pm 13.1 \%$ of controls, $n$ =4).

Interference with the integrity of the cytoskeleton is said to interfere with endocytosis (41). However, the disruption of microtubules and actin filaments by colchicine and cytochalasin B did not affect receptor down-regulation, whether induced by TNF or by endotoxin (Table II), although at least TNF elicits receptor endocytosis of its own receptor. However, agents which are known to inhibit receptor recycling (monen-
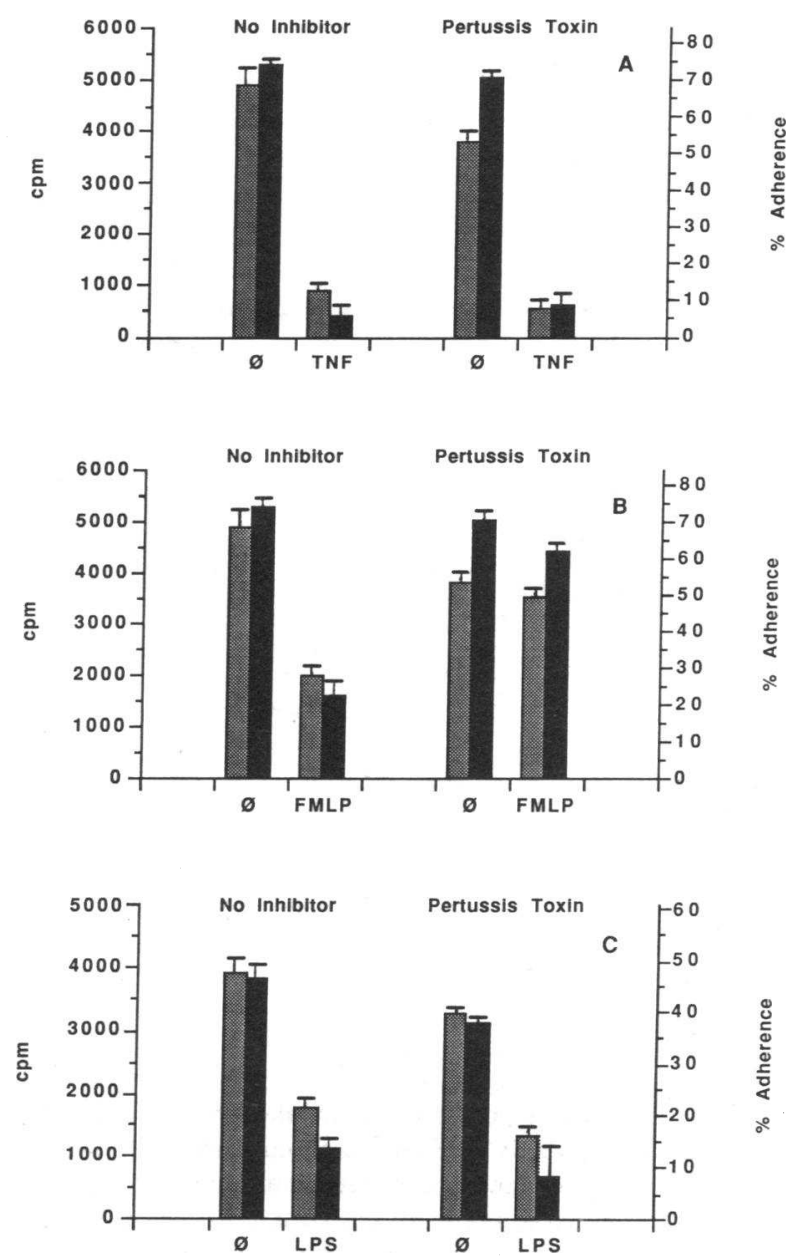

Figure 10. Pertussis toxin sensitivity of deactivation/cross-deactivation and TNF receptor down-regulation by various stimuli. PMN were first incubated with or without pertussis toxin $(1,000 \mathrm{ng} / \mathrm{ml}, 2$ h, $\left.37^{\circ} \mathrm{C}\right)$, then the prestimulus $(A)$ TNF $(500 \mathrm{pg} / \mathrm{ml}),(B)$ FMLP $(0.1$ $\mu \mathrm{M})$, or $(C)$ LPS $(40 \mathrm{ng} / \mathrm{ml})$ was added and cells were reincubated (2 $\mathrm{h}, 37^{\circ} \mathrm{C}$ ). Finally PMN were either washed twice before testing for TNF receptor binding using ${ }^{125} \mathrm{I}-\mathrm{TNF}(5 \mathrm{ng} / \mathrm{ml}$, gray bars) or were restimulated in an adhesion/degranulation assay (40 min,

$37^{\circ} \mathrm{C}$ ) $\pm \mathrm{TNF} 10 \mathrm{ng} / \mathrm{ml}$. Adherence (black bars) due to restimulation alone was calculated as the difference between the total responses of restimulated cells and the responses induced by the prestimulus alone. Control cells restimulated by PMA $(100 \mathrm{ng} / \mathrm{ml})$ instead of TNF were in all cases fully responsive (not shown). TC release showed the same pattern of pertussis toxin sensitivity as adhesion and TNF receptor binding. Values depicted in $A$ and $B$ are from the same experiment. Bars denote mean $\pm 1 / 2$ range of duplicates (only shown when greater than symbol). Three independent experiments gave similar results.

sin) or the degradation of the receptor-ligand complex $\left(\mathrm{NH}_{4}^{+}\right.$, chloroquine), seemed to reinforce receptor down-regulation (Table II). These findings would support the contention that receptor down-regulation by stimuli other than TNF is mediated by endocytosis as well.

\section{Discussion}

Confirming the results of others (42), we could show that recombinant human TNF is a very efficient and potent stimulus 

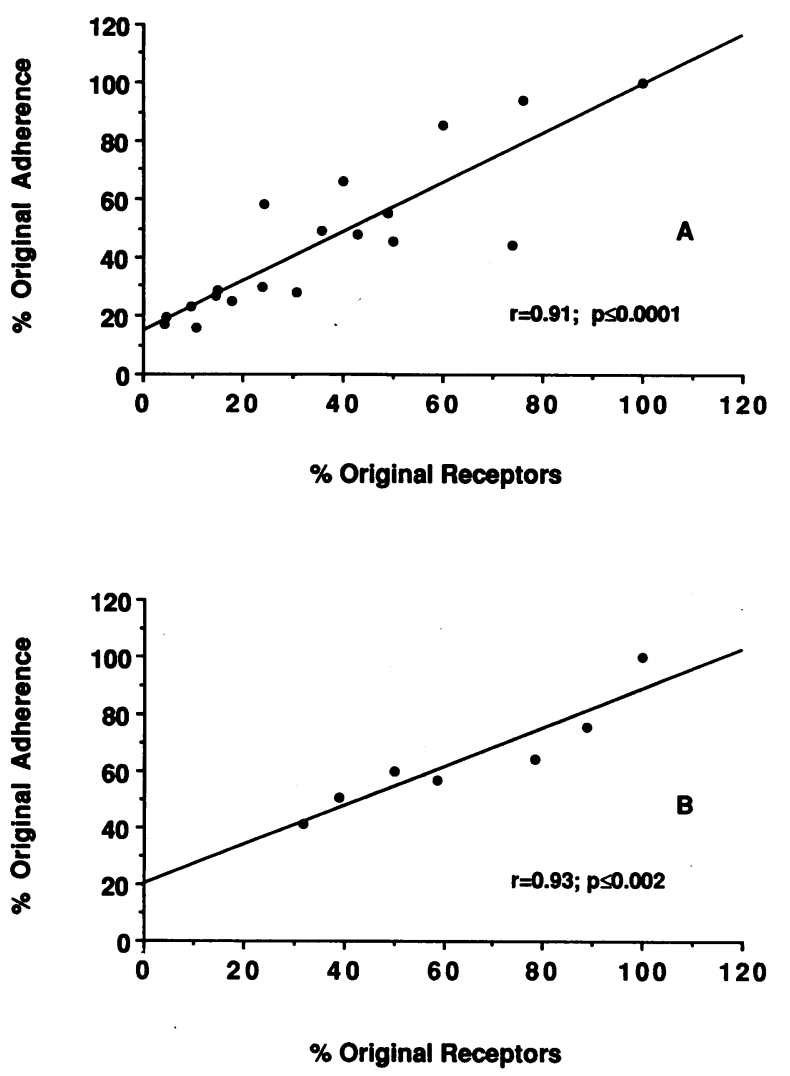

Figure 11. TNF receptor down-regulation and deactivation or crossdeactivation of PMN towards TNF are closely correlated. $(A)$ PMN in HIP were incubated with increasing concentrations of TNF $(33-500 \mathrm{pg} / \mathrm{ml})$ in suspension $\left(2 \mathrm{~h}, 37^{\circ} \mathrm{C}\right)$. Then, cells were either directly restimulated by TNF $(10 \mathrm{ng} / \mathrm{ml})$ and let to adhere (= deactivation assay), or washed three times in PBS-A and tested for receptor binding. Adhesion and TC release were determined as described for Fig. 1. Functional responses due to restimulation alone were calculated as the difference between the total responses of restimulated cells and the responses induced by the preincubation dose alone. Results are expressed as percentage of original adhesion/receptors (no TNF added during preincubation). Results of three independent experiments are shown. Transcobalamine release and TNF receptor expression were similarly correlated $(r=0.89 ; P \leq 0.0001)$. (B) PMN in HIP were incubated with increasing concentrations of LPS $(0.5-20.0 \mathrm{ng} / \mathrm{ml})$ in suspension $\left(2 \mathrm{~h}, 37^{\circ} \mathrm{C}\right)$. All other procedures were as described under $A$ with the exception that PMN were not washed before receptor binding. TC release and TNF receptor expression were similarly correlated $(r=0.95 ; P \leq 0.001)$.

of neutrophil adhesion, degranulation, and respiratory burst in vitro, when tested under adherent conditions. In suspension, however, hardly any exocytosis or activation of the respiratory burst was induced, whether cytochalasin B was added to the cells or not. This probably explains divergent reports of a lack of direct granulocyte activation by TNF, when these cells were tested in suspension $(10,12)$.

Although TNF has been shown to increase pertussis toxin-dependent GTP- $\gamma-S$ binding and GTPase activity in isolated membranes of $\mathrm{HL}-60$ cells (the authors provided no data for whole HL-60 cells [43]), we found TNF to induce PMN responses independently from a pertussis toxin-sensitive $G$ protein, consistent with a recent report that showed TNF priming of PMN to be pertussis toxin-insensitive (44).
Table II. Failure to Inhibit TNF Receptor Down-regulation

\begin{tabular}{|c|c|c|}
\hline & \multicolumn{2}{|c|}{ Preincubation stimulus } \\
\hline & $\begin{array}{c}\text { TNF } \\
(100 \mathrm{pg} / \mathrm{ml})\end{array}$ & $\begin{array}{l}\text { Endotoxin } \\
(40 \mathrm{ng} / \mathrm{ml})\end{array}$ \\
\hline & \multicolumn{2}{|c|}{$c p m$} \\
\hline Cycloheximide $(100 \mu \mathrm{g} / \mathrm{ml})$ & $0 \pm 25^{*}$ & $36 \pm 71$ \\
\hline Actinomycin $\mathrm{D}(10 \mu \mathrm{g} / \mathrm{ml})$ & $39 \pm 15$ & $165 \pm 53$ \\
\hline $\mathrm{NH}_{4}^{+}(10 \mathrm{mM})$ & $90 \pm 18$ & $174 \pm 43$ \\
\hline Chloroquine $(100 \mu \mathrm{M})^{\ddagger}$ & $0 \pm 21$ & $84 \pm 11$ \\
\hline Monensin $(25 \mu \mathrm{M})$ & $6 \pm 7$ & $90 \pm 15$ \\
\hline Colchicine $(100 \mu \mathrm{g} / \mathrm{ml})^{\ddagger}$ & $115 \pm 29$ & $322 \pm 39$ \\
\hline Cytochalasin $B(20 \mu \mathrm{g} / \mathrm{ml})^{\ddagger}$ & $195 \pm 52$ & $158 \pm 41$ \\
\hline Control I (stimulus, no inhibitor) & $265 \pm 65$ & $448 \pm 147$ \\
\hline Control II (no stimulus, no inhibitor) & $2164 \pm 39$ & $2878 \pm 131$ \\
\hline
\end{tabular}

All inhibitors, with the exception of actinomycin $\mathrm{D}$ and cycloheximide $(45 \mathrm{~min})$, were added to the cells at $37^{\circ} \mathrm{C} 10 \mathrm{~min}$ before the respective stimulus. After preincubation in suspension for $2 \mathrm{~h}$ at $37^{\circ} \mathrm{C}$, PMN were washed three times in PBS-A, resuspended in HIP, and assayed for receptor binding $\left(8 \mathrm{~h}\right.$, at $\left.4^{\circ} \mathrm{C}\right)$. Cell counts were always checked before incubation with ${ }^{125} \mathrm{I}-\mathrm{TNF}(1 \mathrm{ng} / \mathrm{ml})$ and results normalized to $5 \times 10^{6} \mathrm{PMN} / \mathrm{ml}$. ${ }^{*}$ Specific binding values are given as mean \pm SD of triplicates. ${ }^{\ddagger}$ Chloroquine $(25 \mu \mathrm{M})$, colchicine (10 $\mu \mathrm{g} / \mathrm{ml})$, and cytochalasin $B(5 \mu \mathrm{g} / \mathrm{ml})$ were tested at lower concentrations as well, with similar results.

TNF mediates its effects by coupling to high-affinity receptors $\left(K_{d} 11.7 \mathrm{pM}\right)$, of which only 520 were found per cell. The higher number of TNF receptors found by others on PMN (14) and HL-60 cells (45) might well be explained, if these authors used the molecular weight of the monomer as the basis for the calculation of receptor number and $K_{d}$ (since gel filtration chromatography suggested that TNF normally occurs as a noncovalent trimer, we calculated our data assuming a molecular mass of $51 \mathrm{kD}$; for details, see Methods). The same considerations hold true for the apparent $K_{d}$, which others, with the exception of Kull et al. ( $3 \mathrm{pM}$ [18]), have generally found one order of magnitude higher than we did $(4,14,45,46)$. In addition, errors may arise from the failure to correct for nonbinding radiolabeled TNF, different methods of estimating specific activity of iodinated TNF, or failure to let the system reach equilibrium $\left(8 \mathrm{~h}\right.$ at $4^{\circ} \mathrm{C}$, in the present study). Finally, a possible interference of nonspecific binding might lead to overestimation of the apparent $K_{\mathrm{d}}$. It must be assumed that the dissociation constant, as calculated by us from Scatchard plots, still overestimates the true $K_{d}$, since the $E_{50}$ observed for adhesion, degranulation, and HMPS was well below the $K_{d}$.

Preexposure to TNF caused functional deactivation of PMN toward restimulation by TNF, which was highly correlated to a concomitant loss of TNF surface receptors by receptor endocytosis, similar to the observations made with FMLP $(22,23,47)$. Although Scatchard plots demonstrated a loss of apparent receptor affinity in parallel to the reduction of TNF receptor number, these results should be viewed with caution. The reduction of receptor expression causes a decrease in total receptor concentration $\left[R_{\mathrm{T}}\right]$, which should yield an apparent $K_{d}$ closer to its true value and therefore lower (32). However, at receptor densities of 120 per cell, as found in some of our experiments after receptor down-regulation, interference from 
nonspecific binding gains in relative importance. This, in turn, would lead to overestimation of the $K_{d}(32)$. In addition, it seems hard to conceive of the biological significance even of a fourfold rise in $K_{d}$ for functional deactivation and cross-deactivation, when PMN are restimulated with doses of TNF that correspond to 20-fold the apparent $K_{\mathrm{d}}$.

Cross-talk between receptors has been recognized for some time: in priming, stimulation of PMN via one class of receptors increases their responses to a second stimulus due either to an increase in receptor number or to modulation of its affinity $(12,48-50)$. Down-regulation of one class of receptors in response to cellular activation by a second class of receptors has been reported, but either the functional relevance of this receptor modulation was not examined (51), or this loss of surface receptors was not accompanied by a specific deactivation of the cells towards the respective ligand but, surprisingly and rather difficult to interpret, subsequent responses were even enhanced $(52,53)$. We have shown that preexposure of granulocytes to a range of stimuli, endogenous such as $\mathrm{C} 5 \mathrm{a}, \mathrm{PAF}$, or $\mathrm{LTB}_{4}$ or exogenous such as endotoxin or FMLP, down-regulated the number of TNF receptors on granulocytes and in all cases concomitantly and statistically highly correlated inhibited PMN adherence, degranulation, and respiratory burst in response to secondary exposure to TNF. In contrast, PMA, which did not alter receptor number, had no effect on TNFinduced functional PMN responses. Moreover, pertussis toxin influenced deactivation or cross-deactivation and TNF receptor numbers always in parallel (Fig. 10). This allows us to conclude that not only in TNF deactivation, similar to the results found for FMLP (47), but in cross-deactivation due to stimuli such as endotoxin or FMLP as well, is the loss of TNF-inducible function causally related to a reduction in the number of TNF receptors.

Others found a similar decrease of TNF receptors on macrophages, which had been preexposed to endotoxin, but failed to demonstrate inhibition of specific binding for PMN (54; results given in percent original binding). The discrepancy between these results and ours is possibly due to the different media used (Krebs-Ringer-phosphate buffer/10\% FCS). FCS, which most likely contains C5a and C5a desarg and probably endotoxin, might cause TNF receptor down-regulation and cross-deactivation before the actual start of the experiment, and hence, cross-deactivation due to the addition of prestimuli would become impossible to evaluate. On the other hand, macrophages, cells which in contrast to PMN can be cultured in vitro, may be less sensible to the culture media used.

A final pathway common to the various stimuli that cause TNF-specific deactivation/cross-deactivation and TNF receptor down-regulation by various stimuli does not include a pertussis toxin-sensitive $G$ protein inasmuch as pertussis toxin inhibited cross-deactivation only with those stimuli, such as FMLP (Fig. $10 \mathrm{~B}$ ), that cause PMN adhesion, degranulation, or chemotaxis via pertussis toxin-sensitive $G$ proteins (38), whereas deactivation by TNF or LPS, which activates PMN independently from pertussis toxin-sensitive $\mathrm{G}$ proteins, was left uninfluenced (Fig. 10, $A$ and $C$ ). Furthermore, TNF-specific deactivation appears to be independent of phospholipase C-generated DAG and activation of protein kinase $C$, in that preincubation of PMN with PMA left both functional responses toward TNF and TNF receptors unaltered (Fig. 5, Table I). Discrepancies with previous reports, which showed down-regulation of TNF receptors upon incubation with PMA
$(55,56)$, may be explained by the different cell systems used. In contrast, the dramatic down-regulation of TNF receptors as seen in preincubation experiments employing the ionophore ionomycin suggest that changes in granulocyte calcium metabolism might be involved in TNF receptor down-regulation and functional deactivation/cross-deactivation.

Down-regulation of TNF receptors (and hence deactivation) induced by TNF itself was shown to result from receptor endocytosis, in agreement with studies carried out on various cell lines $(31,39,57)$. However, the nature of the mechanism for the reduction of receptors owing to preincubation with stimuli other than TNF (cross-deactivation) can only be speculated on: unspecific damage to the cells could be excluded, inasmuch as PMN remained vital and fully responsive towards PMA. Receptor digestion by proteases or oxidative metabolites from activated granulocytes is very unlikely, because $(a)$ all experiments were carried out in scavenger-rich autologous plasma, $(b)$ preincubation of PMN with filtrates of cell lysates caused no alterations in TNF binding, and (c) PMA, which even at $5 \mathrm{ng} / \mathrm{ml}$ causes the strongest degranulation and activation of the respiratory burst in suspension of all stimuli tested, left TNF receptor number and affinity unchanged. None of the effective prestimuli competed with TNF for its receptor. Inhibitors of protein synthesis abolished neither down-regulation induced by TNF nor by endotoxin. As cytochalasin B and colchicine left both endotoxin and TNF-induced receptor down-regulation unaltered, of which the latter was shown to occur by receptor internalization, the negative results obtained with these inhibitors, similar to the ones seen by Peetre et al. (45), cannot be interpreted. The enhancement of receptor down-modulation seen with inhibitors of receptor recycling for both TNF and endotoxin, however, may point to receptor endocytosis as the mechanism of non-TNF-induced receptor reduction. Although electron microscopy and subcellular fractionation techniques are faced with formidable difficulties in view of the low receptor density on PMN, these studies are planned to investigate further into the mechanism of nonTNF-induced modulation of TNF receptors on PMN.

Many of the deleterious consequences of endotoxin in septic shock have been shown to be mediated by TNF (58-60), and elevated serum levels of TNF, as found in gram-negative septicemia, were correlated to poor clinical prognosis $(61,62)$. Aided by the lack of response induced by TNF in suspension, endotoxin- or TNF-induced down-regulation of receptors to this potent stimulus of PMN degranulation and respiratory burst activation in sepsis may thus serve as a self-protective mechanism of the organism to limit the harm inflicted by raised levels of TNF. Under circumstances, however, in which TNF-mediated killing of microorganisms might be of central importance $(63,64)$, deactivation and cross-deactivation of granulocytes could decisively impair host defense. The question of whether deactivation and cross-deactivation of PMN toward TNF are beneficial or harmful to the organism will have to be answered by future in vivo studies using suitable animal models.

\section{Acknowledgments}

The authors wish to thank Mrs. H. Vetsch for excellent technical assistance. Thanks are due to Dr. M. Aguet for many helpful suggestions, and to Dr. R. Flepp for the preparation of C5a and C5a desarg, 
and for performing gel filtration chromatography of TNF as well as for the careful revision of the manuscript.

This work was supported in part by the Swiss National Science Foundation, grants 3.850 .85 and 3.906.88.

\section{References}

1. Williamson, B. D., E. A. Carswell, B. Y. Rubin, J. S. Prendergast, and L. J. Old. 1983. Human tumor necrosis factor produced by human B-cell lines: synergistic cytotoxic interaction with human interferon. Proc. Natl. Acad. Sci. USA. 80:5397-5401.

2. Beutler, B., J. Mahoney, N. Le Trang, P. Pekala, and A. Cerami. 1985. Purification of cachectin, a lipoprotein lipase suppressing hormone secreted by endotoxin-induced RAW 264.7 cells. J. Exp. Med. 161:984-995.

3. Beutler, B., D. Greenwald, J. D. Hulmes, M. Chang, Y.-C. E. Pan, J. Mathison, R. Ulevitch, and A. Cerami. 1985. Identity of tumor necrosis factor and the macrophage-secreted factor cachectin. Nature (Lond.). 318:552-554.

4. Sugarman, B. J., B. B. Aggarwal, P. E. Hass, I. S. Figari, M. A. Palladino, and H. M. Shepard. 1985. Recombinant tumor necrosis factor- $\alpha$ : effects on proliferation of normal and transformed cells in vitro. Science (Wash. DC). 230:943-945.

5. Bertolini, D. R., G. E. Nedwin, T. S. Bringman, D. D. Smith, and G. R. Mundy. 1986. Stimulation of bone resorption and inhibition of bone formation in vitro by human tumor necrosis factor. Nature (Lond.). 319:516-518.

6. Bevilacqua, M. P., J. S. Pober, G. R. Majeau, W. Fiers, R. S. Cotran, and M. A. Gimbrone. 1986. Recombinant tumor necrosis factor induces procoagulant activity in cultured human vascular endothelium: characterization and comparison with the actions of interleukin 1. Proc. Natl. Acad. Sci. USA. 83:4533-4537.

7. Gamble, J. R., J. M. Harlan, S. J. Klebanoff, and M. A. Vadas. 1985. Stimulation of the adherence of neutrophils to umbilical vein endothelium by human recombinant tumor necrosis factor. Proc. Natl. Acad. Sci. USA. 82:8667-8671.

8. Smith, C. W., R. Rothlein, B. J. Hughes, M. M. Mariscalco, H. E. Rudloff, F. C. Schmalstieg, and D. C. Anderson. 1988. Recognition of an endothelial determinant for CD18-dependent human neutrophil adherence and transendothelial migration. J. Clin. Invest 82:1746-1756.

9. Moser, R., B. Schleiffenbaum, P. Groscurth, and J. Fehr. 1989 Interleukin 1 and tumor necrosis factor stimulate human vascular endothelial cells to promote transendothelial neutrophil passage. $J$. Clin. Invest. 83:444-455.

10. Klebanoff, S. J., M. A. Vadas, J. M. Harlan, L. H. Sparks, J. R. Gamble, J. M. Agosti, and A. M. Waltersdorph. 1986. Stimulation of neutrophils by tumor necrosis factor. J. Immunol. 136:4220-4225.

11. Shalaby, M. R., B. B. Aggarwal, E. Rinderknecht, L. P. Svedersky, B. S. Finkle, and M. A. Palladino, Jr. 1985. Activation of human polymorphonuclear functions by interferon- $\gamma$ and tumor necrosis factors. J. Immunol. 135:2069-2073.

12. Atkinson, Y. H., W. A. Marasco, A. F. Lopez, and M. A. Vadas. 1988. Recombinant tumor necrosis factor- $\alpha$ : regulation of $N$-formylmethionylleucylphenyl-alanine receptor affinity and function on human neutrophils. J. Clin. Invest. 81:759-765.

13. Tsujimoto, M., S. Yokota, J. Vilcek, and G. Weissmann. 1986. Tumor necrosis factor provokes superoxide anion generation from neutrophils. Biochem. Biophys. Res. Commun. 137:1094-1 100.

14. Larrick, J. W., D. Graham, K. Toy, L. S. Lin, G. Senyk, and B. M. Fendly. 1987. Recombinant tumor necrosis factor causes activation of human granulocytes. Blood. 69:640-644.

15. Becker, E. L., H. J. Showell, P. M. Henson, and L. S. Hsu. 1974 The ability of chemotactic factors to induce lysosomal enzyme release. I. The characteristics of the release, the importance of surfaces and the relation of enzyme release to chemotactic responsiveness. J. Immunol. 112:2047-2054.

16. Fehr, J., and C. Dahinden. 1979. Modulating influence of che- motactic factor-induced cell adhesiveness on granulocyte function. $J$. Clin. Invest. 64:8-16.

17. Fehr, J., and A. Huber. 1984. Complement-induced granulocyte adhesion and aggregation are mediated by different factors: evidence for non-equivalence of the two cell functions. Immunology. 53:583-593.

18. Kull, F. C., Jr., S. Jacobs, and P. Cuatrecasas. 1985. Cellular receptor for ${ }^{125}$ I-labeled tumor necrosis factor: specific binding, affinity labeling, and relationship to sensitivity. Proc. Natl. Acad. Sci. USA. 82:5756-5760.

19. Niitsu, Y., N. Watanabe, H. Sone, H. Neda, N. Yamauchi, M. Maeda, and I. Urushizaki. 1988. Analysis of the TNF receptor on KYM cells by binding assay and affinity cross-linking. $J$. Biol. $R e$ sponse Modif. 7:276-282.

20. Scheurich, P., U. Ücer, M. Krönke, and K. Pfizenmaier. 1986. Quantification and characterization of high-affinity membrane receptors for tumor necrosis factor on human leukemic cell lines. Int. $J$. Cancer. 38:127-133.

21. Shalaby, M. R., M. A. Palladino, Jr., S. E. Hirabayashi, T. E. Eessalu, G. D. Lewis, H. M. Shepard, and B. B. Aggarwal. 1987. Receptor binding and activation of polymorphonuclear neutrophils by tumor necrosis factor-alpha. J. Leukocyte Biol. 41:196-204.

22. O'Flaherty, J. T., D. L. Kreutzer, H. J. Showell, G. Vitkauskas, E. L. Becker, and P. A. Ward. 1979. Selective neutrophil desensitization to chemotactic factors. J. Cell Biol. 80:564-572.

23. Simchowitz, L., J. P. Atkinson, and I. Spilberg. 1980. Stimulus-specific deactivation of chemotactic factor-induced cyclic AMP response and superoxide generation by human neutrophils. J. Clin. Invest. 66:736-747.

24. Sullivan, S. J., and S. H. Zigmond. 1980. Chemotactic peptide receptor modulation in polymorphonuclear leukocytes. J. Cell Biol. 85:703-711.

25. Dahinden, C., C. Galanos, and J. Fehr. 1983. Granulocyte activation by endotoxin. I. Correlation between adherence and other granulocyte functions, and role of endotoxin structure on biological activity. J. Immunol. 130:857-862.

26. Fernandez, H. N., and T. E. Hugli. 1976. Partial characterization of human C5a anaphylatoxin. I. Chemical description of the carbohydrate and polypeptide portions of human C5a. J. Immunol. 117:1688-1694.

27. Ondetti, M. A., M. E. Condon, J. Reid, E. G. Sabo, H. S. Cheung, and D. W. Cushman. 1979. Design of potent and specific inhibitors of carboxypeptidases A and B. Biochemistry. 18:1427-1430.

28. Fraker, P. J., and J. C. Speck, Jr. 1978. Protein and cell membrane iodinations with a sparingly soluble chloroamide, 1,3,4,6-tetrachloro-3a,6a-diphenylglycoluril. Biochem. Biophys. Res. Commun. 80:849-857.

29. Calvo, J. C., J. P. Radicella, and E. H. Charreau. 1983. Measurement of specific radioactivities in labeled hormones by self-displacement analysis. Biochem. J. 212:259-264.

30. Trucco, M., and S. de Petris. 1981. Determination of equilibrium binding parameters of monoclonal antibodies specific for cell surface antigens. In Immunological Methods, Volume II. Academic Press, Inc., New York. 1-25.

31. Watanabe, N., H. Kuriyama, H. Sone, H. Neda, N. Yamauchi, M. Maeda, and Y. Niitsu. 1988. Continuous internalization of tumor necrosis factor receptors in a human myosarcoma cell line. J. Biol. Chem. 263:10262-10266.

32. Cuatrecasas, P., and M. D. Hollenberg. 1976. Membrane receptors and hormone action. Adv. Protein Chem. 30:251-451.

33. Fehr, J., and H. S. Jacob. 1977. In vitro granulocyte adherence and in vivo margination: two associated complement-dependent functions: studies based on the acute neutropenia of filtration leukophoresis. J. Exp. Med. 146:641-652.

34. Nakagawara, A., and C. F. Nathan. 1983. A simple method for counting adherent cells: application to cultured human monocytes, macrophages and multinucleated giant cells. J. Immunol. Methods. $56: 261-266$. 
35. Gottlieb, C., K.-S. Lau, L. R. Wasserman, and V. Herbert. 1965. Rapid charcoal assay for intrinsic factor (IF), gastric juice unsaturated B12 binding capacity, antibody to IF, and serum unsaturated B12 binding capacity. Blood. 25:875-884.

36. Babior, B. M., R. S. Kipnes, and J. T. Curnutte. 1973. Biological defense mechanisms. The production by leukocytes of superoxide, a potential bactericidal agent. J. Clin. Invest. 52:741-744.

37. Dahinden, C. A., J. Fehr, and T. E. Hugli. 1983. Role of cellsurface contact in the kinetics of superoxide production by granulocytes. J. Clin. Invest. 72:113-121.

38. Spangrude, G. J., F. Sacchi, H. R. Hill, D. E. Van Epps, and R. A. Daynes. 1985. Inhibition of lymphocyte and neutrophil chemotaxis by pertussis toxin. J. Immunol. 135:4135-4143.

39. Tsujimoto, M., and J. Vilcek. 1987. Tumor necrosis factor-induced downregulation of its receptors in HeLa cells. J. Biochem. 102:1571-1577.

40. Scatchard, G. 1949. The attractions of proteins for small molecules and ions. Ann. N.Y. Acad. Sci. 51:660-672.

41. Ruff, M. R., and G. E. Gifford. 1981. Tumor necrosis factor. In Lymphokines. E. Pick, editor. Academic Press, Inc., New York 235-272.

42. Nathan, C. F. 1987. Neutrophil activation on biological surfaces: massive secretion of hydrogen peroxide in response to products of macrophages and lymphocytes. J. Clin. Invest. 80:1550-1560.

43. Imamura, K., M. L. Sherman, D. Spriggs, and D. Kufe. 1988. Effect of tumor necrosis factor on GTP binding and GTPase activity in HL-60 and L929 cells. J. Biol. Chem. 263:10247-10253.

44. Berkow, R. L., and M. R. Dodson. 1988. Biochemical mechanisms involved in the priming of neutrophils by tumor necrosis factor. J. Leukocyte Biol. 44:345-352.

45. Peetre, C., U. Gullberg, E. Nilsson, and I. Olsson. 1986. Effects of recombinant human tumor necrosis factor on proliferation and differentiation of leukemic and normal hemopoietic cells in vitro. Relationship to cell surface receptor. J. Clin. Invest. 78:1694-1700.

46. Aggarwal, B. B., T. E. Eessalu, and P. E. Hass. 1984. Characterization of receptors for human tumor necrosis factor and their regulation by $\gamma$-interferon. Nature (Lond.). 318:665-667.

47. Sklar, L. A., A. J. Jesaitis, and R. G. Painter. 1984. The neutrophil $N$-formyl peptide receptor: dynamics of ligand-receptor interactions and their relationship to cellular responses. In Regulation of Leukocyte Function. R. Snyderman, editor. Contemp. Top. Immunobiol. 14:61-67.

48. Weisbart, R. H., D. W. Golde, and J. C. Gasson. 1986. Biosynthetic human GM-CSF modulates the number and affinity of neutrophil f-Met-Leu-Phe receptors. J. Immunol. 137:3584-3587.

49. English, D., H. E. Broxmeyer, T. G. Gabig, L. P. Akard, D. E. Williams, and R. Hoffman. 1988. Temporal adaptation of neutrophil oxidative responsiveness to $\mathrm{n}$-formyl-methionyl-leucyl-phenylalanine. J. Immunol. 141:2400-2406.

50. Atkinson, Y. H., A. F. Lopez, W. A. Marasco, C. M. Lucas, G. G. Wong, G. F. Burns, and M. A. Vadas. 1988. Recombinant human granulocyte-macrophage colony-stimulating factor (rH GM-
CSF) regulates f Met-Leu-Phe receptors on human neutrophils. Immunology. 64:519-525.

51. Hancock, W. W., M. E. Pleau, and L. Kobzik. 1988. Recombinant granulocyte-macrophage colony-stimulating factor down-regulates expression of IL-2 receptor on human mononuclear phagocytes by induction of prostaglandine. J. Immunol. 140:3021-3025.

52. Walker, F., N. A. Nicola, D. Metcalf, and A. W. Burgess. 1985. Hierarchical down-modulation of hemopoietic growth factor receptors. Cell. 43:269-276.

53. Nicola, N. A., M. A. Vadas, and A. F. Lopez. 1986. Downmodulation of receptors for granulocyte colony-stimulating factor on human neutrophils by granulocyte activating agents. J. Cell. Physiol. 128:501-509.

54. Ding, A. H., E. Sanchez, S. Scrimal, and C. F. Nathan. 1989. Macrophages rapidly internalize their tumor necrosis factor receptors in response to bacterial lipopolysaccharide. J, Biol. Chem. 264:39243929.

55. Unglaub, R., B. Maxeiner, B. Thoma, K. Pfizenmaier, and P. Scheurich. 1987. Downregulation of tumor necrosis factor (TNF) sensitivity via modulation of TNF binding capacity by protein kinase C activators. J. Exp. Med. 166:1788-1797.

56. Johnson, S. E., and C. Baglioni. 1988. Tumor necrosis factor receptors and cytocidal activity are down-regulated by activators of protein kinase C. J. Biol. Chem. 263:5686-5692.

57. Mosselmans, R., A. Hepburn, J. E. Dumont, W. Fiers, and P. Galand. 1988. Endocytic pathway of recombinant murine tumor necrosis factor in L-929 cells. J. Immunol. 141:3096-3100.

58. Beutler, B., I. W. Milsark, and A. C. Cerami. 1985. Passive immunization against cachectin/tumor necrosis factor protects mice from lethal effect of endotoxin. Science (Wash. DC). 229:869-871.

59. Tracey, K. J., B. Beutler, S. F. Lowry, J. Merryweather, S. Wolpe. I. W. Milsark, R. J. Hariri, T. J. Fahey III, A. Zentella, J. D. Albert, et al. 1986. Shock and tissue injury induced by recombinant human cachectin. Science (Wash. DC). 234:470-474.

60. Tracey, K. J., Y. Fong, D. G. Hesse, K. R. Manogue, A. T. Lee, G. C. Kuo, S. F. Lowry, and A. Cerami. 1987. Anti-cachectin/TNF monoclonal antibodies prevent septic shock during lethal bacteremia. Nature (Lond.). 330:662-664.

61. Waage, A., A. Halstensen, and T. Espevik. 1987. Association between tumor necrosis factor in serum and fatal outcome in patients with meningococcal disease. Lancet. $i: 355-357$.

62. Girardin, E., G. E. Grau, J. M. Dayer, P. Roux-Lombard, The J5 Study Group, and P. H. Lambert. 1988. Tumor necrosis factor and interleukin-1 in the serum of children with severe infectious purpura. N. Engl. J. Med. 319:397-400.

63. Bermudez, L. E. M., and L. S. Young. 1988. Tumor necrosis factor, alone or in combination with IL-2, but not IFN- $\gamma$, is associated with macrophage killing of mycobacterium avium complex. J. Immunol. 140:3006-3013.

64. Silberstein, D. S., and J. R. David. 1986. Tumor necrosis factor enhances eosinophil toxicity to Schistosoma mansoni larvae. Proc. Natl. Acad. Sci. USA. 83:1055-1059. 